\title{
WHITE SUPREMACIST TERROR: MODERNIZING OUR APPROACH TO TODAY'S THREAT
}

By Jon Lewis and Seamus Hughes of Program on Extremism at George Washington University and Oren Segal and Ryan Greer for the Center on Extremism at the AntiDefamation League April 2020 


\section{About the Program on Extremism}

The Program on Extremism at George Washington University provides analysis on issues related to violent and non-violent extremism. The Program spearheads innovative and thoughtful academic inquiry, producing empirical work that strengthens extremism research as a distinct field of study. The Program aims to develop pragmatic policy solutions that resonate with policymakers, civic leaders, and the general public.

\section{About the Center on Extremism at the Anti-Defamation League}

ADL's Center on Extremism (COE) is the agency's research and investigative arm, and a clearinghouse of valuable, up-to-the minute information about extremism of all typesfrom white supremacists to Islamic extremists.

For decades, COE analysts have tracked extremist activity in the U.S. and abroad, assisted law enforcement with countless investigations, and helped disrupt and prevent multiple terror attacks. Their law enforcement trainings provide officers with the information they need to protect our country-and themselves-against extremist violence. 


\section{Introduction}

"Basically, they're domestic terrorists. That's why we're here," stated a Georgia Assistant District Attorney on February 14, 2020. ${ }^{1}$ The prosecutor was attempting to explain to a judge why two members of The Base, a violent white supremacist group, should not be let out on bond. Prosecuting domestic terrorists through the state court system instead of the federal system may seem unusual, but it is a result of the mosaic of different approaches federal and state prosecutors use to address the increasing threat of domestic extremism. Cases like these demonstrate the need to examine whether the government is using all the tools at its disposal to address the threat of white supremacist violence. It also underscores the need to ensure that government and law enforcement officials have the resources and knowledge they need to track the criminal activities of violent extremists and, whenever possible, prevent terrorist acts.

The United States has struggled to adapt to a changing domestic terrorism landscape. In the last two months alone, more than a dozen Americans were arrested as part of wideranging investigations into a growing domestic terrorism threat stemming from individuals and groups that have a number of international ties. In response to the upsurgence of these groups, the seriousness of the threat they pose, and the manner in which they operate, U.S. officials have raised alarms. For example, Elizabeth Neumann, the Assistant Secretary for Threat Prevention and Security Policy at the Department of Homeland Security, recently told a Congressional committee that, "it feels like we are at the doorstep of another 9/11...we can see it building and we don't quite know how to stop it."2

This policy paper focuses on the recent arrests of domestic extremists, as well as current efforts by law enforcement to disrupt and counter the growing influence of racially motivated violent extremist ideology-specifically white supremacy-and analyze the current state of enforcement actions against two domestic networks: The Base and Atomwaffen Division. In the accompanying policy recommendations, the authors outline administrative actions, legislative and policy changes, and other possible federal and state legal and prosecutorial powers that could allow for a more comprehensive and effective approach to countering these threats.

\footnotetext{
${ }^{1} \mathrm{John}$ Bailey, "Bond denied for 2 men accused of participating in white supremacist plot to kill Bartow couple," Rome News-Tribune, (February 14, 2020).

https://www.northwestgeorgianews.com/rome/news/local/bond-denied-for-men-accused-ofparticipating-in-white-supremacist/article 4cecae48-4f49-11ea-b96c-ob56cae81146.html

2 "Confronting the Rise in Anti-Semitic Domestic Terrorism, Part II," Committee on Homeland Security, Subcommittee on Intelligence \& Counterterrorism, U.S. House of Representatives, (February 26, 2020). https://homeland.house.gov/activities/hearings/confronting-the-rise-in-anti-semitic-domesticterrorism-part-ii
} 


\section{Where we are now}

The October 2018 release of the National Strategy for Counterterrorism notes that "domestic terrorism in the United States is on the rise, with an increasing number of fatalities and violent nonlethal acts committed by domestic terrorists against people and property in the United States." 3 Three months ago, the Department of Homeland Security released their Strategic Framework for Countering Terrorism and Targeted Violence, which states, "the severity and number of domestic threats have also grown... There has been a concerning rise in attacks by individuals motivated by a variety of domestic terrorist ideologies." 4

In a February 2020 hearing before the House Judiciary Committee, FBI Director Christopher Wray stated that the FBI has, "elevated to the top-level priority racially motivated violent extremism so it's on the same footing in terms of our national threat banding as ISIS and homegrown violent extremism."5

A month prior to Director Wray's comments, his colleague at the Justice Department was raising similar concerns. Thomas Brzozowski, the Counsel for Domestic Terrorism at the Department of Justice, stated the threat of domestic terrorism is no longer confined to our borders: "This issue, in many respects, has become transnational in nature." 6 At the same event, Brzozowski also cautioned against underestimating the severity of the threat: "We are leveraging every tool that we have... to address the issue, but I don't want anybody laboring under the impression that this problem is solved

\footnotetext{
3 “National Strategy for Counterterrorism of the United States," The White House, (October 2018). https://www.whitehouse.gov/wp-content/uploads/2018/10/NSCT.pdf

4 "Department of Homeland Security Strategic Framework For Countering Terrorism and Targeted Violence," U.S. Department of Homeland Security, (September 2019).

https://www.dhs.gov/sites/default/files/publications/19 0920_plcy strategic-framework-counteringterrorism-targeted-violence.pdf

${ }^{5}$ Christopher Wray, "FBI Oversight Hearing," Testimony before the House Judiciary Committee, (February 5, 2020). https://www.c-span.org/video/?468923-1/fbi-director-wray-testifies-oversighthearing. In that same testimony, Director Wray explained that "racially motivated violent extremism" is defined as "any kind of violent extremism that's driven with a kind of racial intent of one sort or another, no matter which direction... we certainly investigate white supremacist motivated violent extremism in the same category that we're talking about... [and also] there are individuals who we categorize and track under the racially motivated violent extremism part of our program management who are African Americans targeting others." It is, however, important to underscore the reality that $55.7 \%$ of domestic extremist-related killings in the U.S. between 2009 and 2018 were specifically committed by white supremacists, while only $3.2 \%$ were committed by left-wing extremists, including anarchists and black nationalists. In 2019, 81\% of extremist-related murders were committed by white supremacists. While it is laudable that the FBI is finally giving much-needed attention to the threat posed by white supremacists, the equivocating nature of Director Wray's testimony highlights the reality that it remains to be seen what this increased attention will look like in practice over a sustained period of time.

${ }^{6}$ Thomas Brzozowski, "Domestic Terrorism At Home and Abroad: A Discussion With the Department of Justice's Domestic Terrorism Counsel," Presentation and Discussion, The Program on Extremism at The George Washington University (January 14, 2020). https://extremism.gwu.edu/event/domesticterrorism-home-and-abroad
} 
because it's not."7 While the FBI and Department of Justice have broad authority and a strong capacity to interdict, investigate, and prosecute crimes, these sentiments suggest that there remain inadequacies, and that the pace and severity of the modern threat may exceed those powers.

These pronouncements are supported by publicly available data. While there is a lack of accurate, reliable government data on this issue, policymakers have long benefited from the work done by groups like ADL (Anti-Defamation League). ${ }^{8}$ For example, ADL's annual Murder and Extremism report counted a total of 42 domestic extremism-related deaths in 17 separate incidents in 2019, the sixth deadliest year since 1970, with three of the previous four years also in the top six. 9 Furthermore, a recent report by ADL's Center on Extremism showed the number of incidents of white supremacist propaganda doubled from 2018 to 2019-from 1,214 to 2,713-the highest number of incidents the organization has recorded. ${ }^{10}$

Even as the COVID-19 pandemic continues, white supremacists have continued their on-the-ground activity, including posting offensive propaganda fliers. In one case, however, a white supremacist was shot and killed by the FBI as he accelerated a plot to bomb a hospital treating coronavirus patients.

On March 24, 2020, Timothy Wilson, of Raymore, Missouri, allegedly planned to use a car bomb to blow up a local hospital currently coping with the coronavirus outbreak in, "an attempt to cause severe harm and mass casualties." 11 Wilson reportedly discussed other possible targets, including a school with a large African-American student population, a synagogue, and a mosque, but authorities believe the COVID-19 pandemic accelerated his plan to commit an act of domestic terrorism against a medical facility. ${ }^{12}$ Officials described Wilson as a, "potentially violent extremist, motivated by racial,

\footnotetext{
${ }^{7}$ Ibid.; Kristen Mitchell, “Domestic Terrorism Is a 'Transnational' Threat,” GW Today, (January 15, 2020). Also see: Weiyi Cai and Simone Landon, "Attacks by White Extremists Are Growing. So Are Their Connections," The New York Times, (April 3, 2019).

https://www.nytimes.com/interactive/2019/04/03/world/white-extremist-terrorism-christchurch.html https://gwtoday.gwu.edu/domestic-terrorism-\%E2\%80\%98transnational\%E2\%80\%99-threat

${ }^{8}$ The Center on Extremism, which tracks and monitors extremists and their activity online, has provided law enforcement officials with intelligence that has helped identify and mitigate threats (including in some of the cases mentioned in this report)

9 "Murder and Extremism in the United States in 2019," Anti-Defamation League, (2020).

https://www.adl.org/murder-and-extremism-2019 The deadliest year according to ADL data was 1995, the year of the Oklahoma City bombing; 2009 was the fifth deadliest year, the year of the Ft. Hood shooting

10 "White Supremacists Double Down on Propaganda in 2019," Anti-Defamation League Center on Extremism, (February 2020). https://www.adl.org/media/14038/download

${ }^{11}$ Adam Goldman, "Man Suspected of Planning Attack on Missouri Hospital Is Killed, Officials Say," The New York Times, (March 25, 2020). https://www.nytimes.com/2020/03/25/us/politics/coronavirus-fbishooting.html

${ }^{12}$ Michael Kosnar, Phil Helsel, "FBI says man killed in Missouri wanted to bomb hospital amid coronavirus epidemic," NBC News, (March 27, 2020). https://www.nbcnews.com/news/us-news/fbisays-man-killed-missouri-wanted-bomb-hospital-amid-coronavirus-n1169166
} 
religious and anti-government animus."13 ADL's Center on Extremism reviewed posts associated with this Telegram account and discovered an individual deeply motivated by white supremacist beliefs. ${ }^{14}$

These trends represent various individual stories that demonstrate the effectiveness-or lack thereof-of current efforts. One illustrative example is that of some members of The Base in Georgia, who are alleged to have been conspiring to commit a double homicide in what appears to be a clear act of targeted political violence. After their arrest, it was reported that the three are potentially facing additional charges, though not of domestic terrorism, which does not exist under federal law. Instead, they may face state charges for stealing and killing a ram in a, "Norse pagan ritual sacrifice." 15 Understandably, to many, something seems awry here.

In order to stem this tide of white-supremacist-driven tragedies, we must assess the ability of current policies and approaches to address these threats and consider whether additional approaches, policies, or laws are necessary. There are a handful of examples of higher profile cases involving violent extremists where law enforcement and other observers have felt that the availability of effective interdiction and penalties were much less certain and accessible than desirable, presenting an unnecessary and potentially dangerous risk.

At the same time, we must carefully consider the potential for misuse and abuse of additional statutes. This is of particular concern where new laws could paint with an overbroad brush and risk sweeping under the rubric of "domestic terrorism" acts of legitimate, non-violent protest, as well as groups and individuals who advocate unpopular political positions. The authors recognize that there has been a history of such abuse in this country, particularly affecting minority communities. Therefore, any recommendations made must apply lessons learned from those injustices.

\footnotetext{
13 "White Supremacists Respond to Coronavirus With Violent Plots and Online Hate," Anti-Defamation League, (March 26, 2020). https://www.adl.org/blog/white-supremacists-respond-to-coronavirus-withviolent-plots-and-online-hate

${ }^{14}$ Ibid.

${ }^{15}$ Bailey, "Bond denied for 2 men accused of participating in white supremacist plot to kill Bartow couple."
} 


\section{Networks}

The seemingly unpredictable instances of lone actor terrorism in the United States undoubtedly pose a unique challenge to law enforcement. ${ }^{16}$ Nowhere is this more evident than in the recent deadly acts of domestic terrorism in Pittsburgh, Pennsylvania, against Jewish worshipers at the Tree of Life Synagogue on October 27, 2018,17 and targeting Hispanics at a Walmart in El Paso, Texas, on August 3, 2019, which left a combined 27 dead and 30 wounded. ${ }^{18}$

In contrast to some other forms of extremism, white supremacist and similar extremist organizations tend not to form cohesive and rigid groups, but instead tend to be more fluid. ${ }^{19}$ At the same time, while most domestic extremists are typically described as lone actors, online platforms serve as non-stop, virtual white supremacist rallies where coordination can happen in real-time, regardless of location. ${ }^{20}$ Indeed, the recent arrests of several geographically disparate but ideologically aligned cells of individuals are emblematic of the increasingly networked nature of this domestic terror threat.

These white supremacists may live thousands of miles apart, but they are united by their belief that whites should have dominance over non-white people, whites should live by themselves in a whites-only society, white people have their own "culture" that is superior to other cultures, and white people are genetically superior to other people. ${ }^{21}$

\footnotetext{
${ }^{16}$ Bruce Hoffman, "Back to the Future: The Return of Violent Far-Right Terrorism in the Age of Lone Wolves," War on the Rocks, (April 2, 2019). https://warontherocks.com/2019/o4/back-to-the-futurethe-return-of-violent-far-right-terrorism-in-the-age-of-lone-wolves/

${ }^{17}$ Campbell Robertson, Christopher Mele and Sabrina Tavernise, "11 Killed in Synagogue Massacre; Suspect Charged With 29 Counts," The New York Times, (September 19, 2019). https://www.nytimes.com/2018/10/27/us/active-shooter-pittsburgh-synagogue-shooting.html ${ }^{18}$ Tim Arango, Nicholas Bogel-Burroughs, and Katie Benner, "Minutes Before El Paso Killing, Hate-Filled Manifesto Appears Online," New York Times, (August 3, 2019).

https://www.nytimes.com/2019/08/03/us/patrick-crusius-el-paso-shooter-manifesto.html; Ben Collins, "Investigators 'Reasonably confident' Texas suspect left anti-immigrant screed, tipped off before attack," NBC News, (August 3, 2019).

https://www.nbcnews.com/news/us-news/investigators-reasonably-confident-texas-suspect-left-antiimmigrant-screed-tipped-n1039031

${ }^{19}$ See: Mark Pitcavage "Surveying the Landscape of the American Far Right," The Program on Extremism at The George Washington University, (August 2019).

https://extremism.gwu.edu/sites/g/files/zaxdzs2191/f/Surveying\%20The\%20Landscape\%20of\%20the\% 20American\%20Far\%20Right_o.pdf

${ }^{20}$ See, e.g., "Gab and 8chan: Home to Terrorist Plots Hiding in Plain Sight," Anti-Defamation League and Network Contagion Research Institute. https://www.adl.org/resources/reports/gab-and-8chan-home-toterrorist-plots-hiding-in-plain-sight

21 “American White Supremacist Groups Exploiting International Connections," Anti-Defamation League, (March 26, 2020). https://www.adl.org/blog/american-white-supremacist-groups-exploiting-

international-connections
} 


\section{The Base}

The Base is a militant, accelerationist, ${ }^{22}$ neo-Nazi organization operating in the United States that emerged in 2018. ${ }^{23} \mathrm{~A}$ recent affidavit in support of arrest warrants for three Base members in Georgia summarizes the core goal of the group as, "uniting white nationalists to prepare for a violent insurgency against various targets, including the United States government and non-white minority groups." 24

The group is believed to have been founded by Rinaldo Nazzaro, an American citizen who is reportedly based in Russia. ${ }^{25}$ The group appears to be organized into regional cells in order to maintain operational security, with each cell having autonomy regarding their actions. ${ }^{26}$

This review of the two sets of arrests in January 2020-of homegrown, networked terror cells-in Maryland, Georgia, Wisconsin, and Michigan presents valuable case studies that demonstrate both the resilient and growing danger of white supremacist extremism and the lengths to which law enforcement and prosecutors are forced to stretch existing legal frameworks to fit this rapidly changing threat landscape.

\section{Maryland Cell}

The arrests of three members of The Base in Maryland-Patrik Jordan Mathews, Brian Mark Lemley Jr., and William Garfield Bilbrough IV-were announced on January 16, 2020. ${ }^{27}$ All three face federal firearms and alien-related charges.

\footnotetext{
22 "White Supremacists Embrace 'Accelerationism," Anti-Defamation League, (April 16, 2019). https://www.adl.org/blog/white-supremacists-embrace-accelerationism

23 “The Base," Anti-Defamation League, https://www.adl.org/resources/backgrounders/the-base

${ }^{24}$ State of Georgia vs Lane, Luke Austin et al., Affidavit in Support of Arrest Warrant, (January 14, 2020). https://extremism.gwu.edu/sites/g/files/zaxdzs2191/f/The\%20Base\%20Georgia\%20Affidavit.pdf

${ }^{25}$ Nazarro has also used the pseudonyms Norman Spear and Roman Wolf when engaging with fellow members of The Base on messaging applications. For more on Nazarro, see: Jason Wilson, "Revealed: the true identity of the leader of an American neo-Nazi terror group," The Guardian, (January 23, 2020). https://www.theguardian.com/world/2020/jan/23/revealed-the-true-identity-of-the-leader-ofamericas-neo-nazi-terror-group; Jason Wilson, "Prepping for a race war: documents reveal inner workings of neo-Nazi group," The Guardian (January 25, 2020).

https://www.theguardian.com/world/2020/jan/25/inside-the-base-neo-nazi-terror-group; Mark Lamoureux and Zachary Kamel, "Neo-Nazi Terror Groups Are Using iFunny to Recruit," Vice News, (November 14, 2019). https://www.vice.com/en us/article/vb5kx3/neo-nazi-terror-groups-are-usingifunny-to-recruit; Ben Makuch and Mack Lamoureux, "Neo-Nazis are Organizing Secretive Paramilitary Training Across America," Vice, (November 20, 2018). https://www.vice.com/en us/article/a3mexp/neo-nazis-are-organizing-secretive-paramilitary-trainingacross-america; Benjamin Wallace, "The Prep-School Past of The Base Founder Rinaldo Nazzaro," New York Magazine, (March 30, 2020). https://nymag.com/intelligencer/2020/03/rinaldo-nazzaro-the-basenorman-spear.html

${ }^{26}$ State of Georgia $v$. Lane, Luke Austin et al., Affidavit in Support of Arrest Warrant, (January 14, 2020). https://extremism.gwu.edu/sites/g/files/zaxdzs2191/f/The\%20Base\%20Georgia\%20Affidavit.pdf

27 "Three Alleged Members of the Violent Extremist Group 'The Base' Facing Federal Firearms and AlienRelated Charges," Office of Public Affairs, Department of Justice, (January 16, 2020). https://www.justice.gov/usao-md/pr/three-alleged-members-violent-extremist-group-base-facingfederal-firearms-and-alien
} 
According to court documents, Lemley and Bilbrough traveled from Maryland to southern Michigan to pick up Mathews after he allegedly crossed illegally into the United States from Canada. ${ }^{28}$ Mathews, a Canadian citizen who disappeared publicly after his membership in The Base was reported, was described as holding a, "leadership position in the Canadian Army Reserve." 29

After picking up Mathews, the group traveled to Georgia where they are alleged to have met with the Georgia Cell of The Base, whose cases will be detailed further below. $3^{0}$ The Maryland Cell reportedly took multiple trips to Georgia to participate in training camps, including one in October 2019 in which Lemley, Mathews, and Bilbrough are alleged to have met with an undercover federal agent and, "about a dozen members of The Base." 31

After the October 2019 training camp, Mathews, Bilbrough, and Lemley returned to Maryland, and Lemley and Mathews subsequently rented an apartment in Delaware to begin, "their planning of violence at a specific event in Virginia, scheduled for January 20, 2020." 32

During this planning phase, court documents indicate that Bilbrough focused his efforts on plans to travel abroad to fight with nationalists in Ukraine. During this time, he attempted to recruit Lemley and Mathews to go to Ukraine with him, a trend that is becoming more and more common for individuals in both The Base and Atomwaffen. 33

\footnotetext{
${ }^{28}$ USA v. Brian Mark Lemley, Jr., Patrik Jordan Mathews, and William Garfield Bilbrough IV, Motion for Detention Pending Trial, (District of Maryland, 2020).

https://extremism.gwu.edu/sites/g/files/zaxdzs2191/f/Maryland\%20Cell\%20Motion\%2ofor\%2oDetenti on\%20Pending\%20Trial.pdf

${ }^{29}$ Ryan Thorpe, "White supremacist in army reserves," Winnipeg Free Press (August 19, 2019). https://www.winnipegfreepress.com/local/white-supremacist-in-army-reserve-553050082.html; See also: "Sheriff: Missing Canadian Soldier Patrik Mathews, Linked To White Supremacist Network, May Be In Minnesota," CBS Minnesota (September 5, 2019). https://minnesota.cbslocal.com/2019/09/05/sheriff-missing-canadian-soldier-patrik-mathews-linkedto-white-supremacist-network-may-be-in-minnesota/; Kelly Weill, "Missing Canadian Bomb Expert With Neo-Nazi Ties May Be In U.S.," Daily Beast, (October 30, 2019). https://www.thedailybeast.com/patrikmathews-missing-canadian-bomb-expert-with-ties-to-neo-nazi-group-the-base-may-be-in-us; Ben Makuch, Mack Lamoureux, and Zachary Kamel, "U.S. Neo-Nazi Terror Group Harboring Missing ExCanadian Soldier: Sources," Vice, (December 5, 2019).

https://www.vice.com/en us/article/8xwwaa/neo-nazi-terror-group-harbouring-missing-ex-soldierpatrik-mathews-sources

${ }^{30}$ Lemley and Bilbrough are also alleged to have participated in two training camps at the same residence in Georgia with the Georgia Cell in August of 2019. The pair allegedly picked up Mathews after the second August training camp and traveled to Georgia several weeks later, where Mathews reportedly remained until after the October 2019 training camp. USA v. Brian Mark Lemley, Jr., Patrik Jordan Mathews, and William Garfield Bilbrough IV, Motion for Detention Pending Trial, (District of Maryland, 2020).

${ }^{31}$ State of Georgia v. Lane, Luke Austin et al., Affidavit in Support of Arrest Warrant, (January 14, 2020). https://extremism.gwu.edu/sites/g/files/zaxdzs2191/f/The\%20Base\%20Georgia\%20Affidavit.pdf

${ }^{32}$ USA v. Lemley, Jr., Mathews, and Bilbrough IV, Motion for Detention Pending Trial, 2020. https://extremism.gwu.edu/sites/g/files/zaxdzs2191/f/Maryland\%20Cell\%20Motion\%20for\%20Detenti on\%20Pending\%20Trial.pdf

${ }^{33}$ The document goes on to note that "At some point in late 2019, Bilbrough at least partially dissociated himself from The Base in order to focus his attention on preparing to travel abroad to fight in Ukraine,
} 
Over the course of approximately two months, law enforcement agents utilized several investigative techniques, including a "sneak-and-peek warrant" and a court-authorized closed-circuit television camera and microphone in the Delaware apartment where Lemley and Mathews lived until their arrest on January 16, 2020.34

During this period, the group is alleged to have made references to, "committing targeted acts of violence," including derailing trains and sabotaging power lines. 35 Throughout the investigation into this cell, the three members allegedly undertook numerous overt acts to prepare for their planned act of targeted violence, including constructing an assault rifle and ordering 1,500 rounds of ammunition. ${ }^{36}$

Law enforcement used a range of tools in the successful disruption of the alleged violent plot in Virginia. Rather than file charges for acts that might seem to hew more closely to the alleged domestic terror plots that were interdicted, prosecutors charged Lemley and Bilbrough with transporting and harboring Mathews - who in turn is charged with entering the country illegally from Canada - while Lemley and Mathews face additional firearms charges. ${ }^{37}$ All three have pleaded not guilty, and criminal proceedings are ongoing. ${ }^{3}$

In order to charge extremists under one of the narrow federal domestic terrorismrelated charges under current law, in the context of plots such as those that Lemley and Bilbrough engaged in, one or more individual plotters must be specifically targeted by law enforcement for actions specific to that act. However, the significance and danger presented by those actions, and the charges they support, risks omitting a broader understanding of the goals and workings of domestic terrorist groups like white supremacist terrorists. That is, firearms charges obfuscate the true threat posed by Lemley and Bilbrough. However, they arguably were what prosecutors had at their disposal, assuming the other troubling actions Lemley and Bilbrough took did not warrant criminal charges. Law enforcement thus may have used the only tools they had to thwart a terrorist threat.

and to recruit other Base members to join him there. However, Bilbrough still remained in contact with full Base members, such as Lemley, Mathews, and others."

${ }^{34}$ Ibid., 17-28.

${ }^{35}$ USA v. Brian Mark Lemley, Jr., Patrik Jordan Mathews, and William Garfield Bilbrough IV, Motion for Detention Pending Trial, (District of Maryland, 2020).

https://extremism.gwu.edu/sites/g/files/zaxdzs2191/f/Maryland\%20Cell\%20Motion\%20for\%20Detenti on\%20Pending\%20Trial.pdf

${ }^{36}$ Ibid.

37 "Three Alleged Members of the Violent Extremist Group 'The Base' Facing Federal Firearms and AlienRelated Charges," Office of Public Affairs, U.S. Department of Justice, (January 16, 2020).

https://www.justice.gov/usao-md/pr/three-alleged-members-violent-extremist-group-base-facingfederal-firearms-and-alien

${ }^{38}$ Ibid.; "3 Men Linked To White Supremacist Group 'The Base' Plead Not Guilty In Maryland,” CBS Baltimore, (February 18, 2020).

https://baltimore.cbslocal.com/2020/02/18/3-men-linked-to-white-supremacist-group-the-base-pleadnot-guilty-in-maryland/ 


\section{Georgia Cell}

On January 17, 2020, barely 24 hours after the arrest of the Maryland Cell of The Base, three members of the group's Georgia Cell were arrested in the midst of allegedly planning to murder a married couple, "whom they identified as having high-profile roles in the far-left group Antifa." 39 The three individuals detained, Luke Austin Lane, Michael Helterbrand, and Jacob Kaderli, face state charges in the Floyd County Superior Court of Georgia of conspiracy to commit murder and of being members of a criminal gang. 40

An undercover federal agent infiltrated the Georgia Cell following an online vetting interview in July 2019. Upon the agent's successful completion of the interview, he was invited to the 105-acre lot owned by Lane and his father-at which point he was welcomed into the group as a member. While at Lane's residence, Lane and Kaderli reportedly, "mentioned their Base contacts located in a variety of locations such as Washington State and the United Kingdom." ${ }^{41}$ Furthermore, during the undercover federal agent's time with The Base cell in Georgia, numerous members of the group are alleged to have traveled to Lane's property and met with the undercover agent while participating in paramilitary training. ${ }^{42}$

Lane, Kaderli and Helterbrand allegedly engaged in numerous meetings to plan the murder of the two individuals they believed to be "Antifa." Lane also reportedly said he wanted to kill an individual identified only as "TB Member" 43 and another Base member

\footnotetext{
${ }^{39}$ Bill Chappell, Merrit Kennedy, and Vanessa Romo, "3 Alleged Members Of Hate Group 'The Base' Arrested In Georgia, Another In Wisconsin,” National Public Radio, (January 17, 2020). https://www.npr.org/2020/01/17/797399834/3-alleged-members-of-hate-group-the-base-arrested-ingeorgia

${ }^{40}$ Jeremy Redmon, "Prosecutor: Alleged Georgia white supremacists planned to kill others," The Atlanta Journal-Constitution, (February 21, 2020). https://www.ajc.com/news/breaking-news/prosecutoralleged-georgia-white-supremacists-planned-kill-others/LDVDlh2DXxeq7umBUWRorO/; Derek Hawkins and Hannah Knowles, "Alleged members of white supremacy group 'the Base' charged with plotting to kill antifa couple," The Washington Post, (January 18, 2020).

https://www.washingtonpost.com/national-security/2020/01/18/the-base-white-supremacist-arrests/; For more on the practice of prosecuting cases of this kind at the state level, see: Susan Hennessey, "The Good Reasons to Not Charge All Terrorists With Terrorism," Lawfare, (December 5, 2015). https://www.lawfareblog.com/good-reasons-not-charge-all-terrorists-terrorism; Lisa Daniels, "Prosecuting Terrorism in State Court," Lawfare, (October 26, 2016). https://www.lawfareblog.com/prosecuting-terrorism-state-court.

${ }^{41}$ State of Georgia v. Lane, Luke Austin et al., Affidavit in Support of Arrest Warrant, (January 14, 2020). https://extremism.gwu.edu/sites/g/files/zaxdzs2191/f/The\%20Base\%20Georgia\%20Affidavit.pdf 42 Ibid.

${ }^{43}$ Based on information from the affidavit, including: 'TB member' being identified as an individual who entered the United States illegally, being present at Lane's residence in October of 2019, speaking about being 'doxxed' by a journalist, and having lived at Lane's property for several months in 2019, 'TB member' is likely Patrick Mathews. This is also supported by Lane's concern that 'TB member' had shared details of the plan with a member of The Base in Maryland, where Mathews was residing following his time in Georgia. See Ibid.
} 
in Maryland because of concerns they would connect Lane to the killings of the Antifa couple if they were carried out. 44

According to the affidavit, while planning the murder of the Antifa members, Lane, Kaderli, and Helterbrand undertook multiple overt acts in furtherance of the plot, including surveilling the intended victims' residence, purchasing brass catching bags, and manufacturing a homemade solvent trap suppressor. 45 Prior to their arrest, the group allegedly discussed plans for future targets who were members of the "television media," and Helterbrand noted he was working on a, "personal server for the group so they would have secure communications." 46 Lane, Kaderli, and Helterbrand pleaded not guilty to the state criminal charges of conspiracy to commit murder and membership in a criminal gang and were denied bail.

\section{Great Lakes Cell}

The final set of recent arrests related to The Base stem from two incidents of synagogue vandalism in Michigan and Wisconsin.

Federal law enforcement arrested Yousef Barasneh on January 17, 2020, for allegedly conspiring to violate citizens' rights in violation of 18 U.S.C. $§ 241.47$ Barasneh, a citizen of Oak Creek, Wisconsin, is alleged to have vandalized a synagogue in Racine, Wisconsin, in September 2019.48 Prior to his arrest, Barasneh is alleged to have traveled to the training camp in Georgia, where he reportedly met the undercover federal agent who had joined The Base. 49

Barasneh is alleged to have been acting at the direction of Richard Tobin, an 18-year-old resident of New Jersey. Tobin was later arrested for directing Barasneh, as well as another synagogue vandal in Michigan, in furtherance of what he dubbed "Operation

\footnotetext{
${ }^{44}$ Chappell, Kennedy, and Romo, "3 Alleged Members of Hate Group 'The Base' Arrested In Georgia, Another In Wisconsin."

${ }^{45}$ Brass catch bags are a popular accessory for AR-style guns, which in this instance would have allegedly been used to collect spent shell casings and avoid leaving any physical evidence at the scene of the crime. Similarly, a solvent trap suppressor is a homemade suppressor to muffle the sound of gunfire. Ibid. ${ }^{46}$ Ibid.

47 "Oak Creek Man Arrested For Conspiracy to Violate Citizens' Rights in Connection With Racine Synagogue Vandalism,” Office of Public Affairs, U.S. Department of Justice, (January 17, 2020). https://www.justice.gov/usao-edwi/pr/oak-creek-man-arrested-conspiracy-violate-citizens-rightsconnection-racine-synagogue

${ }^{48}$ USA v. Yousef Omar Barasneh, Criminal Complaint, (January 16, 2020). https://extremism.gwu.edu/sites/g/files/zaxdzs2191/f/Yousef\%20Omar\%20Barasneh\%20Criminal\%20C omplaint.pdf; USA v. Yousef Omar Barasneh, Indictment, (February 4, 2020). https://extremism.gwu.edu/sites/g/files/zaxdzs2191/f/Yousef\%20Omar\%20Barasneh\%20Indictment.pd f; USA v. Yousef Omar Barasneh, Order Setting Conditions of Release, (January 17, 2020). https://extremism.gwu.edu/sites/g/files/zaxdzs2191/f/Yousef\%20Omar\%20Barasneh\%20Order\%20Sett ing\%20Conditions\%20of\%20Release.pdf; Mark Lamoureux, Ben Makuch and Zachary Kamel, "Man Arrested for Synagogue Vandalism Was Active in Two Militant Neo-Nazi Groups," Vice, (November 20, 2019). https://www.vice.com/en us/article/pa75jk/man-arrested-for-synagogue-vandalism-was-activein-two-militant-neo-nazi-groups

${ }^{49}$ Ibid.
} 
Kristallnacht," an homage to a pogrom carried out against Jewish residents of Nazi Germany. 50

While the recent arrests of members of The Base have shone a light on the inner workings of the group, ${ }^{51}$ another group with significant transnational ties, Atomwaffen Division, remains a potent domestic threat. ${ }^{2}$

\section{$\underline{\text { Atomwaffen Division }}$}

Atomwaffen Division (AWD) is a neo-Nazi group based in the United States that went public in 2015.53 As the criminal complaint against one of its members notes, "AWD membership consists of mostly white males between the ages of approximately 16 to 30 years of age who all believe in the superiority of the white race," and who organize in small, semi-autonomous groups in order to, "achieve a common goal of challenging the established laws, social order, and government via terrorism and violent acts." 54 Although the group originated in the United States, it is reported to have a significant

\footnotetext{
${ }^{50}$ Jeremy Roebuck, "South Jersey Man Accused in Synagogue Vandalisms, Revealing Dark Network of Neo-Nazi Organizing Online,” The Philadelphia Inquirer, (November 15, 2019). https://www.inquirer.com/news/richard-tobin-synagogue-vandalism-the-base-white-supremacistracine-wisconsin-hancock-michigan-20191115.html; Joe Atmonavage, "Suspect who Allegedly Wanted to Attack African-Americans with Machete at Mall is 18-year-old Firefighter," NJ.com, (November 19, 2019). https://www.nj.com/news/2019/11/suspect-who-allegedly-wanted-to-attack-african-americans-withmachete-at-mall-is-18-year-old-firefighter.html

${ }^{51}$ While a discussion of the various distinct and related ideologies of both groups are outside of the scope of this paper, it is important to recognize that membership in these two groups are not mutually exclusive. As noted by the government motion for detention for the Maryland Base Cell, "Since 2018, The Base has been building a coalition of white supremacist members within the United States and abroad through, among other things, online chat rooms, in-person meetings, propaganda, and military training. The Base's membership includes members of other white supremacist organizations, including Atomwaffen Division, a violent neo-Nazi terror group linked to several hate crimes. The Base recruits white supremacists and is particularly interested in applicants with military and explosives backgrounds."

USA v. Lemley, Jr., Mathews, and Bilbrough IV, 2020, 2.

https://extremism.gwu.edu/sites/g/files/zaxdzs2191/f/Maryland\%20Cell\%20Motion\%2ofor\%20Detenti on\%20Pending\%20Trial.pdf

${ }^{52}$ Anna Schecter and Rich Schapiro, "Influential neo-Nazi eats at soup kitchens, lives in government housing," NBC News, (November 26, 2019). https://www.nbcnews.com/news/us-news/influential-neonazi-eats-soup-kitchens-lives-government-housing-n1091681

${ }^{53}$ For more, see: “Atomwaffen Division (AWD)," Anti-Defamation League. https://www.adl.org/resources/backgrounders/atomwaffen-division-awd; Jonah Engel Bromwich, "What is Atomwaffen, A Neo-Nazi Group, Linked to Multiple Murders," The New York Times, (February 12, 2018). https://www.nytimes.com/2018/02/12/us/what-is-atomwaffen.html; "California Murder Suspect Said to Have Trained With Extremist Hate Group,” ProPublica, (January 26, 2018).

https://www.propublica.org/article/california-murder-suspect-atomwaffen-division-extremist-hategroup; Anna Schecter and Rich Schapiro, "Influential neo-Nazi eats at soup kitchens, lives in government housing," NBC News, (November 26, 2019). https://www.nbcnews.com/news/us-news/influential-neonazi-eats-soup-kitchens-lives-government-housing-n1091681

${ }^{54}$ USA v. Conor Climo, Complaint, (District of Nevada, August 9, 2019).

https://extremism.gwu.edu/sites/g/files/zaxdzs2191/f/Conor\%20Climo\%20Complaint.pdf
} 
presence overseas with branches in Canada, 55 the United Kingdom, ${ }^{6}$ Germany, 57 and potentially the Baltic States. 58

While recent law enforcement actions against Atomwaffen Division have likely prevented acts of targeted violence, at least five murders since 2017 have implicated members of the group. In May 2017, two Atomwaffen members in Florida were allegedly

\footnotetext{
${ }^{55}$ Mack Lamoureux and Ben Makuch, "Atomwaffen, an American Neo-Nazi Terror Group, Is in Canada," (June 19, 2018). https://www.vice.com/en us/article/a3a8ae/atomwaffen-an-american-neo-nazi-terrorgroup-is-in-canada; Mack Lamoureux and Ben Makuch, "An American Neo-Nazi Group Has Dark Plans for Canada," Vice, (July 10, 2018). https://www.vice.com/en us/article/ev847a/an-american-neo-nazigroup-has-dark-plans-for-canada

${ }^{56}$ Paul Jackson, Transnational Neo-Nazism In The USA, United Kingdom and Australia, The Program on Extremism at The George Washington University, (February 2020).

https://extremism.gwu.edu/sites/g/files/zaxdzs2191/f/Jackson\%20-

\%20Transnational\%20neo\%20Nazism\%20in\%20the\%20USA\%2C\%20United\%20Kingdom\%20and\%20 Australia.pdf; Graham Macklin, "The Evolution of Extreme-Right Terrorism and Efforts to Counter It in the United Kingdom," CTC Sentinel 12, no. 1 (January 2019). https://ctc.usma.edu/evolution-extremeright-terrorism-efforts-counter-united-kingdom/

Jamie Grierson, "UK to ban neo-Nazi Sonnenkrieg Division as a terrorist group,” The Guardian, (February 24, 2020). https://www.theguardian.com/uk-news/2020/feb/24/uk-ban-neo-nazisonnenkrieg-division-terrorist-group

${ }^{57}$ Some of the links are more prominently displayed publicly than others. For example, "In the summer of 2018, Atomwaffen announced the formation of a German cell, accompanied by video footage showing an AWD member unfurling an Atomwaffen flag, with Wewelsburg castle, a prominent landmark in Nazi history, pictured in the background" See: "Atomwaffen Division (AWD)," Anti-Defamation League. https://www.adl.org/resources/backgrounders/atomwaffen-division-awd; "Neo-Nazi 'Atomwaffen Division' Spreads Fear in Germany,” Spiegel International, (November 13, 2019).

https://www.spiegel.de/international/germany/neo-nazi-group-atomwaffen-division-takes-root-ingermany-a-1295575.html

${ }^{58}$ Little on tangible links between Feuerkrieg Division and Atomwaffen Division is publicly available. Some sources suggest that the groups share ideological underpinnings and that Feuerkrieg Division modeled itself after Atomwaffen Division, but stop short of suggesting the groups have a direct operational connection. While a criminal complaint against Nevada resident Conor Climo, who was "communicating with individuals who identified with the white supremacist extremist group Atomwaffen Division" prior to his arrest describes Feuerkrieg Division as "a splinter group" of Atomwaffen that "shares the same ideology and beliefs," it provides no evidence to suggest a direct operational link. However, due to the fluid and online nature of these organizations, more research is needed to determine the relationship between the two group. See: Tess Owen, "Neo-Nazi Accused of Plotting Bombings Wanted to Recruit Middle Schoolers, Chats Reveal," Vice News, (August 15, 2019). https://www.vice.com/en us/article/vb5mpx/neo-nazi-accused-of-plotting-bombings-wanted-torecruit-middle-schoolers-chats-reveal; "Feuerkrieg Division (FKD)," Anti-Defamation League, https://www.adl.org/resources/backgrounders/feuerkrieg-division-fkd; Subcomandante X, "Telegram Messages Reveal Details about Neo-Nazi Group Feuerkrieg Division,” Medium.com, (October 2, 2019). https://medium.com/americanodyssey/telegram-messages-feuerkrieg-division-jarrett-william-smitharrested-neo-nazi-34d8dbd32653; Subcomandante X, "Feuerkrieg Division Attempts to Recruit in the United States, Announces Creation of More 'Cells," Medium.com, (August 8, 2019). https://medium.com/americanodyssey/feuerkrieg-division-atomwaffen-division-neo-nazi-far-rightgroup-ace4e698abc1; USA v. Conor Climo, Complaint, (District of Nevada, August 9, 2019). https://extremism.gwu.edu/sites/g/files/zaxdzs2191/f/Conor\%20Climo\%20Complaint.pdf
} 
killed by one of their roommates, a fellow Atomwaffen member who had recently renounced his affiliation with the group and converted to Islam. 59

Brandon Russell, the fourth roommate and founder of Atomwaffen Division, was arrested shortly after the double homicide at his Florida apartment. However, law enforcement first allowed Russell to leave the crime scene after he claimed he was going to visit his father who lived nearby ${ }^{60}$ Instead, he drove to the house of a fellow Atomwaffen Division member, William Tschantre, who, "promptly quit his job and withdrew his life savings of \$3,000," and left with Russell. 61 The pair were detained two days later in Key West, with no suitcases or other personal belongings, and in possession of "two long rifles and ammunition that he [Russell] had purchased after leaving the Tampa area." 62 According to the arresting officer, "when we found the weapons, we were convinced we had just stopped a mass shooting." 63

Despite this, Russell was charged and sentenced to just five years in prison after pleading guilty to possessing an unregistered destructive device and for unlawful storage of explosive material, stemming from law enforcement's discovery of the explosive compound HMTD and various other explosive precursors in his residence. 64 While serving his five-year sentence on federal explosives charges, he was able to release a

\footnotetext{
${ }^{59}$ The two individuals, Andrew Oneschuk and Jeremy Himmelman, were found dead in a Florida apartment they were sharing with the purported founder of Atomwaffen Division - Brandon Russell - and Devon Arthurs, who is currently awaiting trial for both murders. Arthurs has since been declared mentally incompetent to proceed. For more information, see: A.C. Thompson, "An Atomwaffen Member Sketched a Map to Take the Neo-Nazis Down. What Path Officials Took Is a Mystery," ProPublica, (November 20, 2018). https://www.propublica.org/article/an-atomwaffen-member-sketched-a-map-to-take-the-neonazis-down-what-path-officials-took-is-a-mystery; State of Florida $v$. Devon Ryan Arthurs, Defendant's Memorandum of Defendant's History of Incompetency to Proceed Due to Mental Illness, (February 25, 2020).

https://extremism.gwu.edu/sites/g/files/zaxdzs2191/f/Devon\%20Arthurs\%20Defense\%20Memo\%20of \%20Defendant\%20History\%200f\%20Incompetency\%20to\%20Proceed\%20Due\%20to\%20Mental\%20Ill ness.pdf

Jason Dearen and Michael Kunzelman, "Deadly shooting ends friendships forged in neo-Nazi group," Associated Press, (August 22, 2017). https://apnews.com/222eafof $330 e 4$ cdf812634fobaf.3d5ca/Deadlyshooting-ends-friendships-forged-in-neo-Nazi-group

${ }^{60}$ Janet Reitman, “All-American Nazis: Inside the Rise of Fascist Youth in the U.S.," Rolling Stone, (May 2, 2018).

https://www.rollingstone.com/politics/politics-news/all-american-nazis-628023/

${ }^{61}$ Ibid.

62 "Neo-Nazi Leader Sentenced to Five Years in Federal Prison for Explosives Charges," Office of Public Affairs, U.S. Department of Justice, (January 9, 2018).

https://www.justice.gov/opa/pr/neo-nazi-leader-sentenced-five-years-federal-prison-explosives-charges

63 "Documenting Hate: New American Nazis," PBS Frontline, (November 12, 2018). https://www.pbs.org/wgbh/frontline/film/documenting-hate-new-american-nazis/

64 "Neo-Nazi Leader Sentenced to Five Years in Federal Prison for Explosives Charges," Office of Public Affairs, U.S. Department of Justice, (January 9, 2018).

https://www.justice.gov/opa/pr/neo-nazi-leader-sentenced-five-years-federal-prison-explosives-charges
} 
video, "ostensibly recorded from inside the United States Penitentiary in Atlanta," in which he, "thanked his comrades for their "undying loyalty and courage."”65

In December 2017, Nicholas Giampa ${ }^{66}$ was alleged to have murdered his girlfriend's parents after his girlfriend's mother reported Giampa's online neo-Nazi views to his school's principal.67 In January 2018, authorities arrested Atomwaffen member Sam Woodward in California and charged him with the murder of 19-year old college sophomore Blaze Bernstein, a former high school classmate. ${ }^{68}$ County prosecutors subsequently announced Woodward would receive a hate crime sentencing enhancement for allegedly targeting Bernstein due to his sexual orientation. 69

On February 26, 2020, the Federal Bureau of Investigation (FBI) announced the arrest of five members of Atomwaffen-John Cameron Denton, Kaleb Cole, Cameron Brandon Shea, Taylor Ashley Parker-Dipeppe, and Johnny Roman Garza-across four states.70

${ }^{65}$ Ibid.; A.C. Thompson and Ali Winston, "White Supremacists Share Bomb-Making Materials in Online Chats," ProPublica, (November 2, 2017). https://www.propublica.org/article/white-supremacists-sharebomb-making-materials-in-online-chats

${ }^{66}$ A.C. Thompson, Ali Winston, and Jake Hanrahan, "Inside Atomwaffen As It Celebrates a Member for Allegedly Killing a Gay Jewish College Student," ProPublica, (February 23, 2018).

https://www.propublica.org/article/atomwaffen-division-inside-white-hate-group

${ }^{67}$ Giampa's twitter account, which featured a skeleton wearing a Nazi SS military hat and a bio which stated "Read Siege" (a reference to James Mason's publication that is one of the foundational works of Atomwaffen Division) is detailed here: Jessica Schulberg and Luke O'Brien, "We Found The Neo-Nazi Twitter Account Tied To A Virginia Double Homicide," Huffpost, (January 4, 2018).

https://www.huffpost.com/entry/nicholas-giampa-neo-nazi-teenager-murder-girlfriends-parentsvirginia n 5a4do797e4boboe5a7aa4780; For more on Giampa, see: Justin Jouvenal, "Va. teen accused of killing girlfriend's parents to be tried as an adult," The Washington Post, (September 24, 2019).

https://www.washingtonpost.com/local/public-safety/va-teen-accused-of-killing-girlfriends-parents-tobe-tried-as-an-adult/2019/09/24/3e628fae-af13-11e9-aoc9-6d2d7818f3da story.html; Schulberg and O’Brien, "We Found The Neo-Nazi Twitter Account Tied To A Virginia Double Homicide."

68 "California Murder Suspect Said to Have Trained With Extremist Hate Group," ProPublica, (January 26, 2018). https://www.propublica.org/article/california-murder-suspect-atomwaffen-divisionextremist-hate-group

${ }^{69}$ Emily Shapiro, “1 year after Blaze Bernstein's killing, parents look to turn alleged hate crime into 'movement of hope'," ABC News, (December 30, 2018).

https://abcnews.go.com/US/year-blaze-bernsteins-killing-parents-turn-alleged-hate/story?id=59754707; Priyanka Boghani, Marcia Robiou, Catherine Trautwein, "Three Murder Suspects Linked to Atomwaffen: Where Their Cases Stand," PBS Frontline, (June 18, 2019).

${ }^{70}$ USA v. Cameron Brandon Shea, Kaleb J. Cole, Taylor Ashley Parker-Dipeppe, and Johnny Roman Garza, Complaint for Violation, (Western District of Washington, 2020).

https://extremism.gwu.edu/sites/g/files/zaxdzs2191/f/Cole\%20Shea\%20Parker-

Dipeppe\%20Garza\%20Complaint.pdf; USA v. John Cameron Denton, Criminal Complaint, (Eastern District of Virginia, 2020).

https://extremism.gwu.edu/sites/g/files/zaxdzs2191/f/John\%20Cameron\%20Denton\%20Criminal\%20C omplaint.pdf; Rachel Weiner and Matt Zapotosky, "Five arrested, accused of targeting journalists as part of neo-Nazi Atomwaffen group," The Washington Post, (February 26, 2020).

https://www.washingtonpost.com/local/public-safety/propublica-named-him-as-an-atomwaffen-leaderfeds-say-he-struck-back/2020/02/26/c9548ac4-57e5-11ea-ab68-101ecfec2532 story.html; Sundell, "FBI arrests 4 suspected neo-Nazi members after threats to KING 5 journalist and activists."

https://www.king.5.com/article/news/investigations/seattle-extremist-group-arrest/281-0e64ade6-of72427c-9f74-66f $471882 \mathrm{fb} 2$ 
The FBI made clear at their press conference that, "[t]he group had gone from rhetoric to the commission of illegal acts." 71

John Cameron Denton, arrested in Montgomery, Texas, was described by the Department of Justice as a, "[f]ormer Atomwaffen Division leader."72 Denton is charged with conspiring with John William Kirby Kelley, two unnamed foreign nationals living outside the United States, and an unnamed 'Individual 1' to commit an offense against the United States, specifically interstate threats to injure.73

These threats to injure were a series of "swatting" calls, in which false reports of an emergency, typically a violent crime or hostage situation, trigger a law enforcement response to an unwitting individual's address. 74

According to the affidavit, Denton engaged in a months-long campaign from November, 2018, to February, 2019, in which he and his alleged co-conspirators placed hundreds of such swatting calls. 75 In sum, the government alleges that Denton's swatting conspiracy impacted 134 different law enforcement agencies. ${ }^{7}$

As with the government investigation into The Base, law enforcement introduced an undercover agent to Denton, who, "unknowingly had a meeting with an undercover FBI

\footnotetext{
${ }^{71}$ Allison Sundell, "FBI arrests 4 suspected neo-Nazi members after threats to KING 5 journalist and activists," King 5 News, (February 26, 2020).

https://www.king5.com/article/news/investigations/seattle-extremist-group-arrest/281-0e64ade6-of72$427 \mathrm{c}-9 \mathrm{f} 74-66 \mathrm{f} 471882 \mathrm{fb} 2$

72 "Former Atomwaffen Division Leader Arrested for Swatting Conspiracy," Office of Public Affairs, U.S. Department of Justice, (February 26, 2020).

https://www.justice.gov/usao-edva/pr/former-atomwaffen-division-leader-arrested-swatting-conspiracy

${ }^{73}$ The affidavit describes individual 1 as a U.S. citizen who is currently charged by state authorities for his role in this offense. USA v. John Cameron Denton, Affidavit, (Eastern District of Virginia, 2020). https://extremism.gwu.edu/sites/g/files/zaxdzs2191/f/John\%20Cameron\%20Denton\%20Affidavit.pdf

${ }^{74}$ For more on the practice of swatting, see: Brittan Heller and Aaron Sussman, "No Longer Just a Prank: 'Swatting' Incident Turns Deadly in Kansas,” Anti-Defamation League, (January 10, 2018).

https://www.adl.org/blog/no-longer-just-a-prank-swatting-incident-turns-deadly-in-kansas; ADL is now undertaking a national campaign, Backspace Hate, designed to support victims and targets of online hate and harassment by raising awareness and passing legislation to better hold perpetrators accountable for their actions online. See: https://www.adl.org/backspace-hate for a map of the United States with a state-by-state listing of the range of cyberhate laws currently on the books. ADL also supported the Online Safety Modernization Act in the 115th Congress, which would have, among other provisions, created a federal criminal law against swatting.

${ }^{75}$ The affidavit details swatting events that took place during this conspiracy, including swatting events which targeted Old Dominion University, the Alfred Street Baptist Church in Old Town Alexandria, and a Cabinet official living in Northern Virginia.

USA v. John Cameron Denton, Affidavit, 2020; Associated Press News, "Former Old Dominion University student charged in 'swatting' ring linked to neo-Nazis," WTKR 3, (January 15, 2020).

https://wtkr.com/2020/01/15/former-old-dominion-university-student-charged-in-swatting-ringlinked-to-neo-nazis/; Nick Boykin, "Man charged for a threat made against an African-American church in Alexandria," WUSA 9, (last updated January 15, 2020).

https://www.wusa9.com/article/news/local/virginia/man-charged-for-a-threat-made-against-anafrican-american-church-in-alexandria/65-452a74ba-6e36-4791-9bd.5-1ede9508317e;

${ }^{76}$ USA v. John Cameron Denton, Affidavit, 2020.
} 
special agent in his home."77 During this meeting, Denton is alleged to have stated that he swatted journalists who had reported on Denton's affiliation with Atomwaffen Division, including ProPublica, and stated that, "if he was 'raided' for swatting ProPublica then it would be good for Atomwaffen Division because the swatting would be seen as a top-tier crime." 78

On the same day as Denton's arrest, federal charges were announced in Washington State against four other members of Atomwaffen Division, accusing them of conspiring to mail threatening communications and to commit cyberstalking.79 An indictment filed on March 4, 2020, also charged the four with three additional counts of mailing threatening communications. 80

According to the complaint, the group, "conducted research online to identify journalists and activists to threaten, specifically targeting Jews and other minorities... with the intent to cause fear of bodily harm, harass, intimidate, and retaliate against unfavorable reporting." ${ }_{11}$ The complaint alleges that the group took overt acts in furtherance of this conspiracy in Arizona, Texas, Florida, and Washington, specifically creating and mailing or affixing threatening posters to the homes of, "an editor of a local Jewish publication...two individuals associated with the Anti-Defamation league," as well as a residence they believed belonged to a journalist. ${ }^{82}$

One of the individuals arrested, Taylor Ashley Parker-Dipeppe, ${ }^{83}$ a 20-year-old resident of Spring Hill, Florida, reportedly picked up an unnamed man in St. Petersburg, Florida, and traveled to a residence they believed belonged to a news reporter. ${ }^{84}$ Once there, they

\footnotetext{
${ }^{77}$ Ibid.

${ }^{78}$ Ibid.

79 "Arrests in Four States of Racially Motivated Violent Extremists Targeting Journalists and Activists," Office of Public Affairs, U.S. Department of Justice, (February 26, 2020). https://www.justice.gov/opa/pr/arrests-four-states-racially-motivated-violent-extremists-targetingjournalists-and-activists

${ }^{80}$ USA v. Cameron Brandon Shea, Kaleb J. Cole, Taylor Ashley Parker-Dipeppe, and Johnny Roman Garza, Indictment, (Western District of Washington, 2020).

https://extremism.gwu.edu/sites/g/files/zaxdzs2191/f/Cole\%20Shea\%20Parker-

Dipeppe\%20Garza\%20Indictment.pdf

${ }^{81}$ USA v. Shea, Cole, Parker-Dipeppe, and Garza, Complaint for Violation, 2020.

${ }^{82}$ Ibid.

${ }^{83}$ Parker-Dipeppe is reported to be a former resident of New Jersey, who moved to Tampa, Florida sometime after graduating from high school in 2017. See: Joe Atmonavage, "20-year-old alleged Neo-Nazi from N.J. charged by feds for plot to intimidate activists, journalists," NJ.com, (February 28, 2020). https://www.nj.com/news/2020/02/20-year-old-alleged-neo-nazi-from-nj-charged-by-feds-for-plot-tointimidate-activists-journalists.html; Dan Sullivan, Jack Evans, Mark Puente, “'I don’t know what happened to him.' Alleged Spring Hill neo-Nazi held without bail,” Tampa Bay Times, (February 27, 2020). https://www.tampabay.com/news/crime/2020/02/27/alleged-spring-hill-neo-nazi-charged-inintimidation-plot-held-withoutbail/?utm expid=.rZxRlJIoT86fmAabR1Jv8w.o\&utm referrer=https\%3A\%2F\%2Fwww.google.com\%2F ${ }^{84}$ Dan Sullivan, "Spring Hill man among four accused in neo-Nazi harassment plot," Tampa Bay Times, (February 26, 2019). The criminal complaint also notes that Parker-Dipeppe drove from Spring Hill with an unnamed woman, who he dropped off in Tampa before traveling to St. Petersburg. Parker-Dipeppe
} 
reportedly placed threatening posters on the residence, with messages such as, "We are watching, we are no one, we are everyone, we know where you live, do not fuck with us," and, "You have been visited by your local Nazis." 85

Additionally, the Order of Detention for Parker-Dipeppe merits further analysis. The Magistrate Judge in the Middle District of Florida, in ordering Parker-Dipeppe detained without bail, notes that:

the organization [Atomwaffen Division] has roots in this area and is a white supremacist organization intending to threaten, if not kill, minorities. Thus, an organizer was found in possession of explosive materials. Notably, the defendant, when arrested, was in possession of several knives and brass knuckles. Consequently, the defendant and his cohorts clearly present a danger to the community. ${ }^{86}$

Before the FBI announced the charges against Kaleb Cole-one of the current leaders of Atomwaffen Division-he and fellow AWD member Aidan Bruce-Umbaugh were the subjects of a routine traffic stop in Post, Texas, on November 4, 2019. When law enforcement searched the vehicle, they seized several rifles from the trunk of the vehicle, including an AR-15 rifle, two AK-47 rifles, and approximately 2,000 rounds of ammunition. Bruce-Umbaugh and Cole both stated that all the firearms belonged exclusively to Bruce-Umbaugh. ${ }^{87}$

Following Bruce-Umbaugh's arrest, he stated that he and Cole were traveling from Washington state to Houston, Texas to, "meet with some friends." 88 On a jail call with his mother following his arrest, Bruce-Umbaugh stated that, "it's probably good the cops caught me off guard when they did." 89 Though not explicitly stated in court documents,

also purchased a baseball bat, hooded sweatshirt and sunglasses at a Goodwill store before arriving in Tampa. Ibid.

${ }^{85}$ The poster also contained a hazard symbol consistent with what is commonly used on Atomwaffen materials. USA v. Shea, Cole, Parker-Dipeppe, and Garza, Complaint for Violation, 2020.

${ }^{86}$ USA v. Taylor Ashley Parker-Dipeppe, Order of Detention, (Middle District of Florida, 2020). The organizer, Brandon Russell, is the founder of Atomwaffen Division who was sentenced to 5 years in prison in 2018 for possessing an unregistered destructive device and for unlawful storage of explosive material. Russell pleaded guilty to these charges in 2017. See: "Neo-Nazi Leader Sentenced to Five Years in Federal Prison for Explosives Charges" Office of Public Affairs, U.S. Department of Justice, (January 9, 2018). https://www.justice.gov/opa/pr/neo-nazi-leader-sentenced-five-years-federal-prison-explosives-charges ${ }^{87}$ USA v. Aiden Bruce-Umbaugh, Factual Resume, (Northern District of Texas, 2019). https://extremism.gwu.edu/sites/g/files/zaxdzs2191/f/Bruce-Umbaugh\%20Factual\%2oResume.pdf; Nick R. Martin, “The Atomwaffen Evidence,” The Informant, https://www.informant.news/p/theatomwaffen-evidence

${ }^{88}$ USA v. Aiden Bruce-Umbaugh, Criminal Complaint, (Northern District of Texas, 2019). https://extremism.gwu.edu/sites/g/files/zaxdzs2191/f/Bruce-Umbaugh\%20Complaint.pdf

${ }^{89}$ At the time they were pulled over, a Sig Sauer, $9 \mathrm{~mm}$ pistol was found under the passenger seat, where Bruce-Umbaugh was seated. This statement was seized upon by the prosecution, who referenced it in their Amended Response to Bruce-Umbaugh's Motion for a Review of the Pretrial Detention Order, stating "defendant implies that he would have taken violent action against police officers had he not been caught 'off guard'." See: USA v. Aiden Bruce-Umbaugh, Government's Amended Response, (Northern District of Texas, 2019). 
evidence suggests that Bruce-Umbaugh took responsibility for both the rifles and a small amount of drugs that was also found in the car because Kaleb Cole was prohibited from possessing firearms due to an Extreme Risk Protection Order in Washington. ${ }^{90}$

In October, 2019, it was reported that following his return from a trip to Eastern Europe, Cole had been the subject of an Extreme Risk Protection Order, the imposition of which was described at the time as a "a novel use" of an order that traditionally, "allow[s] families or law enforcement to petition a judge to remove guns from someone believed to present a danger to themselves or others." ${ }^{1}$ According to the Order, "Cole was traveling to Ukraine and other areas of Eastern Europe...posing in photos with the Atomwaffen Division flag." 92 The Order also noted that Cole held several "hate camps" in which he, "participated in recent firearms training and recruitment efforts," in Washington with other Atomwaffen Division members. Moreover, he was, "identified by Canadian authorities as a possible member of an organization that may engage in terrorism and Cole [was] permanently banned from entry into Canada." 93 The petition for the Order expressed concern that Cole went, "from espousing hate to now taking active steps or preparation for an impending 'race war." 94

As highlighted in this paper, domestic terror networks like The Base and Atomwaffen Division often walk a narrow line between constitutionally-protected speech and illegal action. Supporters of giving law enforcement additional tools believe the recent arrests show how diligent and even creative law enforcement must be in considering the tools and legal authorities that can be used to disrupt these networks and individual plotters. Years of inaction and what some deem a lack of adequate tools, together with an apparent underestimation of the threat posed by these groups has allowed them to

https://extremism.gwu.edu/sites/g/files/zaxdzs2191/f/Bruce-

Umbaugh\%20Govt\%20Amended\%20Response\%20to\%20Defense\%20Motion\%20for\%20Review\%20of\% 20Detention\%20Order 0.pdf

${ }^{90}$ Amy Radil, "Snohomish County men accused of neo-Nazi ties are still in Texas," KUOW Public Radio, (January 11, 2020). https://www.kuow.org/stories/king-county-says-two-local-men-accused-of-neo-nazities-still-in-texas

${ }^{91}$ The U.S. Customs and Border Protection TECS Incident Log Query, found in the exhibits of the Extreme Risk Protection Order, detail Cole's statements regarding his travel in Eastern Europe: "Subject stated they were coming back from a 25-day trip to Europe. Subject first traveled to Prague, Czech Republic where they stayed at 3 Crowns hotel for 5 days. Subject then traveled by bus to Wroclaw, Poland where they stayed at Hostel Fitness for 3 days. Subject then went to Kiev, Ukraine where they stayed at Airbnb for 12 days. Subject stated they visited the Patriotic War Museum and attended metal music festival while in Kiev. Subject then traveled to Krakow, Poland where they stayed at Holiday Inn hotel for 2 days, and then back to Prague for 2 days...Subject stated he did not meet with anyone while in Europe, except few people from UK, who he met while walking the streets in Kiev." The CBP interview makes no mention of the photos found on Cole's phone of Bruce-Umbaugh and Cole posing in front of Auschwitz, or the 12/17/18 dated photo in Cole's phone of 7 individuals posing with an Atomwaffen Division flag while performing a Nazi salute. See: Ibid; Seattle Police Department v. Kaleb James Cole, Petition for an Extreme Risk Protection Order, (Superior Court of Washington for King County, 2019).

https://extremism.gwu.edu/sites/g/files/zaxdzs2191/f/Kaleb\%20Cole\%20Petition\%20for\%20an\%20Extr eme\%20Risk\%20Protection\%20Order.pdf

${ }^{92}$ Seattle Police Department v. Kaleb James Cole, Petition for an Extreme Risk Protection Order, 2019

${ }^{93}$ Ibid.

${ }^{94}$ Ibid. 
flourish. They have shown the ability and desire to expand and recruit both domestically and internationally, even from behind bars, and inspire others to commit acts of targeted violence, in their name or otherwise. 95

While these cases show the threat posed by Atomwaffen Division domestically, its international offshoots and linkages also require analysis. Sonnenkrieg Division, described as the U.K. arm of the group, emerged in 2018 following the arrest of two U.K.-based individuals who encouraged an attack against Prince Harry. ${ }^{66}$ The nature of the relationship between Atomwaffen Division and its foreign branches or affiliates will likely become clearer as the investigation and prosecution of these groups take place in the United States and overseas. If, however, groups like Atomwaffen were to be considered a foreign terrorist organization, the penalties for supporting them would be severe.

\footnotetext{
${ }^{95}$ Janet Reitman, “How Did a Convicted Neo-Nazi Release Propaganda From Prison?” Rolling Stone, (May 25, 2018). https://www.rollingstone.com/politics/politics-news/how-did-a-convicted-neo-nazirelease-propaganda-from-prison-628437/

${ }^{96}$ Jamie Grierson, "UK to ban neo-Nazi Sonnenkrieg Division as a terrorist group," 2020.; Daniel De Simone, "Teenage neo-Nazi admits terror offences," $B B C$.
} 


\section{Policy Recommendations}

Recommendation 1: Examine options related to the designation of foreign white supremacist groups as foreign terrorist organizations (FTOs)

- The State Department has designated 69 groups as foreign terrorist organizations, an extraordinarily powerful tool that supports a range of law enforcement actions against those groups. While most designated groups are Islamist-inspired extremists, groups like the FARC and IRA are also designated. The State Department should examine the intelligence and consider whether its designation authority could apply to certain racially and ethnically motivated extremist groups, and particularly white supremacist groups, outside the United States.

While international ties of U.S.-based extremists to foreign white supremacist groups may be the exception rather than the rule, the State Department nevertheless should determine whether there is evidence sufficient to designate any of the existing foreign white supremacist organizations as foreign terrorist organizations. At present, none of the current 69 organizations on the FTO list is a white supremacist organization.

Designation could be a powerful tool to leverage against foreign white supremacists and other racially and ethnically motivated terrorists, as well as Americans who provide support to them. Similar provisions have been implemented by Germany, 97 Canada, 98 and the United Kingdom. 99 If a group were found to meet the threshold based on U.S. law, such a designation could enhance investigative and prosecutorial tools, allow for closer cooperation with foreign partners, and allow for the full toolkit of federal government responses currently used to address foreign and foreign-inspired terrorism.

\footnotetext{
${ }^{97}$ Peter Kuras, “Germany Has a Neo-Nazi Terrorism Epidemic," Foreign Policy (July 2, 2019). https://foreignpolicy.com/2019/07/02/germany-has-a-neo-nazi-terror-epidemic/

98 "Currently listed entities," Public Safety, Government of Canada. https://www.publicsafety.gc.ca/cnt/ntnl-scrt/cntr-trrrsm/lstd-ntts/crrnt-lstd-ntts-en.aspx; "Canada adds neo-Nazi groups Blood \& Honour, Combat 18 to list of terror organizations," Global News, (June 26, 2019).https://globalnews.ca/news/5432851/canada-adds-neo-nazi-groups-blood-honour-and-combat18-to-list-of-terror-organizations/; Mack Lamoureux, "Canada Adds Far-Right Groups to Terror Watch List for First Time," Vice, (June 27, 2019). https://www.vice.com/en uk/article/8xz77k/canada-combat18-blood-honour-far-right-groups-terror-watch-list; Stewart Bell, "Neo-Nazi group Blood \& Honour removed from Facebook after terrorist designation,” Global News, (June 27, 2019) https://globalnews.ca/news/5439431/blood-honour-banned-from-facebook/ ${ }^{99}$ Jamie Grierson, "UK to ban neo-Nazi Sonnenkrieg Division as a terrorist group," The Guardian, (February 24, 2020).https://www.theguardian.com/uk-news/2020/feb/24/uk-ban-neo-nazisonnenkrieg-division-terrorist-group? $\mathrm{CMP}=$ share btn tw; Vikram Dodd and Jamie Grierson, "Fastestgrowing UK terrorist threat is from far right, say police," The Guardian, (September 19, 2019). https://www.theguardian.com/uk-news/2019/sep/19/fastest-growing-uk-terrorist-threat-is-from-farright-say-police; Benn Quinn, “Rise in rightwing extremists held under anti-terror laws in UK," The Guardian, (September 5, 2019). https://www.theguardian.com/uk-news/2019/sep/05/rise-in-rightwingextremists-held-under-anti-terror-laws-in-uk
} 
Such a designation can be used to confront both foreign and domestic actors who conspire or attempt to provide or receive support from such white supremacist FTOs. ${ }^{100}$

In October 2019, over 40 members of Congress wrote a letter to Secretary of State Pompeo requesting information on, "why the State Department has failed to include certain overseas violent white supremacist extremist groups on the Foreign Terrorist Organization (FTO) list.”101

This letter was followed by a House Resolution introduced by Congressman Max Rose (D-NY) on March 3, 2020, which calls on the Administration to designate foreign violent white supremacist groups as Foreign Terrorist Organizations. ${ }^{102}$ It identifies the Nordic Resistance Movement, the National Action Group, Atomwaffen Division, Blood and Honour, and Combat 18 as violent white supremacist organizations that the Members suggested could be worthy of such designation. ${ }^{103}$

While the designation of a group such as Azov Battalion as a foreign terrorist organization would undoubtedly be controversial, there is evidence to suggest the group would fit the legal threshold for designation under current State Department guidelines. ${ }^{104}$ Azov Battalion has engaged in the recruitment of Americans to travel and fight in their organization through its Western Outreach Center, ${ }^{105}$ and Azov's ties to

${ }^{100}$ For more, see: Amy Collins, "If the Shoe Fits, Designating Foreign White Supremacy Extremist Groups," War on the Rocks, (February 4, 2020). https://warontherocks.com/2020/02/if-the-shoe-fitsdesignating-foreign-white-supremacy-extremist-groups/; Haroro J. Ingram, Jon Lewis, "How to act against domestic terrorists - and their foreign supporters" The Hill, (September 15, 2019).

https:/thehill.com/opinion/criminal-justice/460955-how-to-act-against-domestic-terrorists-and-theirforeign-supporters; John R. Allen, "White-Supremacist Violence Is Terrorism," The Atlantic, (February

24, 2020). https://www.theatlantic.com/ideas/archive/2020/02/white-supremacist-violenceterrorism/606964/; Max Rose and Ali Soufan, "We Once Fought Jihadists. Now We Battle White Supremacists," The New York Times, (February 11, 2020).

https://www.nytimes.com/2020/02/11/opinion/politics/white-supremacist-terrorism.html; Tess Owen, "The U.S. Doesn't Prosecute Far-Right Extremists as Terrorists. Here's How It Could," Vice News, (June 20, 2019). https://www.vice.com/en us/article/3k3y43/the-us-doesnt-prosecute-far-right-extremistsas-terrorists-heres-how-it-could

${ }^{101}$ Congressman Max Rose Et al., to The Honorable Michael Pompeo, (October 16, 2019). https://maxrose.house.gov/uploadedfiles/2019.10.16 rose fto letter to state.pdf

${ }^{102}$ For the full text of the resolution, see: https://maxrose.house.gov/uploadedfiles/2020.03.02 fto resolution.pdf ${ }^{103}$ Ibid.

${ }^{104}$ The group must be foreign, must engage in terrorist activity as defined in section 212 (a)(3)(B) of the INA (8 U.S.C. § 1182(a)(3)(B)) or terrorism, as defined in section 140(d)(2) of the Foreign Relations Authorization Act, Fiscal Years 1988 and 1989 (22 U.S.C. § 2656f(d)(2)), or retain the capability and intent to engage in terrorist activity or terrorism; and organization's terrorist activity or terrorism must threaten the security of U.S. nationals or the national security (national defense, foreign relations, or the economic interests) of the United States. For this reason, the designation of a group such as Atomwaffen Division, which was founded and operates primarily in the United States-albeit with international connections and overseas supporters (whether ideological or operational) would appear to pose substantial legal and constitutional concerns.

${ }^{105}$ Anna Nemtsova and Christopher Dickey, “Ukraine’s Anti-Russia Azov Battalion: ‘Minutemen' or NeoNazi Terrorists?” The Daily Beast, (November 15, 2019). https://www.thedailybeast.com/ukraines-antirussia-azov-battalion-minutemen-or-neo-nazi-terrorists; Oleksiy Kuzmenko, “Defend the White Race': 
American groups like the Rise Above Movement ${ }^{106}$ have been well-documented. ${ }^{107}$ While Congress finally banned arms sales to the Azov Battalion - after three years of attempts - in its omnibus spending bill, more decisive action may be needed to prevent Americans from materially supporting this group. ${ }^{108}$

Azov, however, is not the only foreign organization attempting to expand its international profile. Russian ultra-nationalist groups, including the Russian Imperial Movement (RIM) have recently sought to cultivate ties with domestic neo-Nazi and white supremacist groups. ${ }^{109}$

So too has Feuerkrieg Division, the neo-Nazi group established in 2018 and believed to be based in Estonia. Feuerkrieg Division has a membership that is increasingly

American Extremists Being Co-Opted by Ukraine's Far-Right," Bellingcat, (February 15, 2019).

https://www.bellingcat.com/news/uk-and-europe/2019/02/15/defend-the-white-race-americanextremists-being-co-opted-by-ukraines-far-right/

106 “Rise Above Movement (R.A.M.)," Anti-Defamation League.

https://www.adl.org/resources/backgrounders/rise-above-movement-ram; "Four Local Members of White Supremacy Group Face Federal Charges in Attacks at Political Rallies across California," Office of Public Affairs, U.S. Department of Justice (October 24, 2018). https://www.justice.gov/usaocdca/pr/four-local-members-white-supremacy-group-face-federal-charges-attacks-political-rallies ${ }^{107}$ For more information, see: Ali Winston and A.C. Thompson, "American Hate Group Looks to Make Allies in Europe," ProPublica, (July 5, 2018). https://www.propublica.org/article/robert-rundo-denisnikitin-hooligans-europe-hate-group; Christopher Miller, "Azov, Ukraine's Most Prominent Ultranationalist Group, Sets Its Sights On U.S., Europe,” Radio Free Europe/Radio Liberty, (November 14, 2018). https://www.rferl.org/a/azov-ukraine-s-most-prominent-ultranationalist-group-sets-itssights-on-u-s-europe/29600564.html; https://www.adl.org/media/13531/download; A.C. Thompson, Ali Winston, and Darwin Bond Graham, "Racist, Violent, Unpunished: A White Hate Group's Campaign of Menace," ProPublica, (October 19, 2017). https://www.propublica.org/article/white-hate-groupcampaign-of-menace-rise-abovemovement?utm campaign $=$ sprout\&utm medium $=$ social\&utm source $=$ twitter\&utm content $=15085149$ 98; A.C. Thompson, Ali Winston, Jake Hanrahan, "Ranks of Notorious Hate Group Include Active-Duty Military," Propublica, (May 3, 2018). https://www.propublica.org/article/atomwaffen-division-hategroup-active-duty-military

${ }^{108}$ Rebecca Kheel, "Congress bans arms to Ukraine militia linked to neo-Nazis," The Hill, (March 27, 2018). https://thehill.com/policy/defense/380483-congress-bans-arms-to-controversial-ukrainianmilitia-linked-to-neo-nazis

${ }^{109}$ The designation of such a group would also indicate a significant step taken to confront state actors who seek to destabilize democracies through their support for foreign and domestic non-state actors. See Haroro J. Ingram, Jon Lewis, "How to act against domestic terrorists - and their foreign supporters" The Hill, (September 15, 2019). https://thehill.com/opinion/criminal-justice/46095.5-how-to-act-againstdomestic-terrorists-and-their-foreign-supporters; For more on the Russian Imperial Movement, see: Elizabeth Grimm Arsenault, Joseph Stabile, "Confronting Russia's Role in Transnational White Supremacist Extremism,” Just Security, (February 6, 2020).

https://www.justsecurity.org/68420/confronting-russias-role-in-transnational-white-supremacistextremism/; Michael Carpenter, "Russia Is Co-opting Angry Young Men," The Atlantic, (August 29, 2018). https://www.theatlantic.com/ideas/archive/2018/o8/russia-is-co-opting-angry-youngmen/568741/; Jeff Seldin, "White Supremacists Lead New Wave of Foreign Fighters," Voice of America, (September 30, 2019). https://www.voanews.com/usa/white-supremacists-lead-new-wave-foreignfighters; Andrew Roth, "A right-wing militia trains Russians to fight the next war - with or without Putin," (January 2, 2017). https://www.washingtonpost.com/world/europe/a-right-wing-militia-trainsrussians-to-fight-the-next-war--with-or-without-putin/2017/01/02/fo6b5ce8-b71e-11e6-939c91749443c5e5_story.html 
American. Motivated by the same ideological underpinnings as Atomwaffen Division, including James Mason's Siege, the group appears in the criminal complaints of both Jarrett William Smith (whose case will be examined below) and Conor Climo.

Climo, who was arrested on August 8, 2019, in Las Vegas, Nevada, was charged with one count of possession of an unregistered firearm. ${ }^{110}$ According to the complaint, Climo had been under investigation since April of 2019 based on information that he was communicating with members of Atomwaffen Division. ${ }^{111}$ An FBI confidential human source (CHS) established contact online with Climo, during which Climo discussed his plans to commit an act of targeted violence, namely "setting fire to a synagogue" as well as his desire to make Molotov cocktails and improvised explosive devices. ${ }^{112}$

Notably, during the execution of the search warrant at Climo's residence, he stated that he, "began to communicate online, through the encrypted chat application Discord, with members of the Neo-Nazi group, The Feuerkrieg Division (FKD)." ${ }^{113}$ However, Climo claims he left the online FKD group because "he became bored with the group and their inaction." 114 Climo ultimately pleaded guilty and faces a maximum ten-year sentence. ${ }^{115}$

While the recruitment of Americans by organizations like FKD is cause for concern, another form of mobilization may be flying under the radar: The Soufan Center estimates that approximately 35 Americans have traveled to Ukraine to fight on either side of the ongoing conflict. ${ }^{116}$ While detailed information on the newest wave of American foreign fighters remains an under-researched aspect of this mobilization, anecdotal evidence in the investigation into members of both The Base and Atomwaffen shows a persistent and pervasive desire among Americans to travel to Ukraine and fight

\footnotetext{
${ }^{110}$ Joe Sexton, "Las Vegas Man Arrested in Plots Against Jews Was Said to Be Affiliated with Atomwaffen Division," ProPublica, (August 14, 2019). https://www.propublica.org/article/las-vegas-man-conorclimo-was-said-to-be-affiliated-with-atomwaffen-division

${ }^{111}$ USA v. Conor Climo, Criminal Complaint, (District of Nevada, 2020). https://extremism.gwu.edu/sites/g/files/zaxdzs2191/f/Conor\%20Climo\%20Complaint.pdf

${ }^{112}$ Ibid. The Detention Order also notes that, "when the search warrant was executed, the defendant had in his possession, in his room with the door unlocked and unsecured, an AR-15 and a bolt action rifle." Climo also admitted that he discussed plans for violent attacks against the Anti-Defamation League and a local bar. USA v. Conor Climo, Order of Detention Pending Trial, (District of Nevada, 2020). https://extremism.gwu.edu/sites/g/files/zaxdzs2191/f/Conor\%20Climo\%2oDetention\%20Order.pdf; USA v. Conor Climo, Plea Agreement, (District of Nevada, 2020). https://extremism.gwu.edu/sites/g/files/zaxdzs2191/f/Conor\%20Climo\%20Plea\%20Agreement.pdf ${ }^{113}$ USA v. Conor Climo, Criminal Complaint, (District of Nevada, 2020). https://extremism.gwu.edu/sites/g/files/zaxdzs2191/f/Conor\%20Climo\%20Complaint.pdf ${ }^{114}$ Ibid.

${ }^{115}$ USA v. Conor Climo, Plea Agreement, (District of Nevada, 2020). https://extremism.gwu.edu/sites/g/files/zaxdzs2191/f/Conor\%20Climo\%20Plea\%20Agreement.pdf; Nick R. Martin, "Three Guilty Pleas,” The Informant, (February 11, 2019).

https://www.informant.news/p/three-guilty-pleas

116 "White Supremacy Extremism: The Transnational Rise of the Violent White Supremacist Movement," The Soufan Center, (September 2019). https://thesoufancenter.org/wpcontent/uploads/2019/o9/Report-by-The-Soufan-Center-White-Supremacy-Extremism-TheTransnational-Rise-of-The-Violent-White-Supremacist-Movement.pdf
} 
with extremist groups. ${ }^{117}$

One such individual who expressed that desire is Jarrett William Smith, a specialist assigned to the First Infantry Division at Fort Riley, Kansas, ${ }^{118}$ who was arrested in September, 2019, and charged with two counts of distributing explosives information and one count of threatening interstate communications. ${ }^{119}$

The Magistrate Judge's order for detention also notes that Smith, "stated that after his Army contract ends he intends to join the Azov Battalion or Right Sector Volunteer Corps ${ }^{120}$-notably, after being told that he would be expected to kill if he did so-or to aid one of the organizations fighting ISIS in the Middle East." ${ }^{121}$ Smith's case also

${ }^{117}$ For more information, see: Kuzmenko, “'Defend the White Race’: American Extremists Being CoOpted by Ukraine's Far-Right.”; Reitman, "All-American Nazis: Inside the Rise of Fascist Youth in the U.S.”; Ben Makuch, Mack Lamoureux, and Zachary Kamel, "Neo-Nazi Terror Group The Base Linked to the War in Ukraine," Vice, (February 6, 2020). https://www.vice.com/en us/article/y3m3eg/neo-naziterror-group-the-base-linked-to-the-war-in-ukraine; Redmon, "Prosecutor: Alleged Georgia white supremacists planned to kill others." The Atlanta Journal-Constitution, (February 21, 2020).

https://www.ajc.com/news/breaking-news/prosecutor-alleged-georgia-white-supremacists-planned-killothers/LDVDlh2DXxeq7umBUWRorO/

${ }^{118}$ Smith is one of a number of recent cases of the spread of extremism within the military. For more information, see: Mark Pitcavage, "White Supremacy in the Military," Testimony Before the House Subcommittee on Military Personnel, (February 11, 2020). https://www.adl.org/news/article/markpitcavages-testimony-before-the-house-subcommittee-on-military-personnel

Dave Philipps, "White Supremacism in the U.S. Military, Explained," The New York Times, (February 27, 2019). https://www.nytimes.com/2019/02/27/us/military-white-nationalists-extremists.html; Kathleen Belew, "Veterans and White Supremacy," The New York Times, (April 15, 2014).

https://www.nytimes.com/2014/04/16/opinion/veterans-and-white-supremacy.html; Lecia Brooks, "SPLC Testifies Before Congress on Alarming Incidents of White Supremacy in the Military," Southern Poverty Law Center, (February 11, 2020). https://www.splcenter.org/news/2020/02/11/splc-testifiescongress-alarming-incidents-white-supremacy-military; "Alarming Incidents of White Supremacy in the Military-How to Stop It?" Hearing before the House Armed Services Committee, Subcommittee on Military Personnel, (February 11, 2020). https://armedservices.house.gov/2020/2/subcommittee-onmilitary-personnel-hearing-alarming-incidents-of-white-supremacy-in-the-military-how-to-stop-it; Jeff McCausland, "Inside the U.S. military's battle with white supremacy and far-right extremism," NBC News, (May 25, 2019). https://www.nbcnews.com/think/opinion/inside-u-s-military-s-battle-whitesupremacy-far-right-ncna1010221;

${ }^{119}$ USA v. Jarrett William Smith, Criminal Complaint, (District of Kansas, 2019). https://extremism.gwu.edu/sites/g/files/zaxdzs2191/f/Jarrett\%20William\%20Smith\%20Criminal\%20C omplaint.pdf; Mike Levine, "FBI arrests Army soldier who allegedly discussed plans to bomb major American news network," ABC News, (September 23, 2019). https://abcnews.go.com/Politics/fbi-arrestsarmy-soldier-allegedly-discussed-plans-bomb/story?id=65802902; Phil Helsel, "Soldier who discussed attack in U.S. pleads guilty to distributing bomb instructions," NBC News, (February 11, 2020). https://www.nbcnews.com/news/us-news/army-soldier-who-discussed-attack-u-s-pleads-guiltydistributing-n1134571

${ }^{120}$ For more on Azov Battalion, see: Michael Colborne, "There's One Far-Right Movement That Hates the Kremlin,”

"https://foreignpolicy.com/2019/04/17/theres-one-far-right-movement-that-hates-the-kremlin-azovukraine-biletsky-nouvelle-droite-venner/; "The Transnational Network that Nobody Is Talking About," The Soufan Center, (March 2019). https://thesoufancenter.org/intelbrief-the-transnational-networkthat-nobody-is-talking-about/; Will Cathcart, Joseph Epstein, "How Many Neo-Nazis Is the U.S. Backing in Ukraine?” Daily Beast, (April 14, 2017).

${ }^{121}$ USA v. Jarrett William Smith, Detention Order, (District of Kansas, 2019). 
evidences the unclear and converging nature of both domestic and overseas extremist organizations, specifically Smith's links to Feuerkrieg Division. ${ }^{122}$

Crucially, the designation of foreign terrorist organizations is known to be a potent tool, in the U.S. and overseas. Such designation allows the FBI a wide legal basis to investigate and surveil Americans connected to banned overseas groups, but the Bureau-rightly and constitutionally-is significantly more limited in its ability to pursue domestic organizations and individuals associated with them. ${ }^{123}$ Furthermore, while the narrow and targeted FTO and concomitant material support measures could function as an effective precision tool with which to target a group such as Atomwaffen, it is ill-suited to combat the rise of lone actor violence, and simply cannot be used against individuals who do not align themselves with a designated foreign organization. For that reason among others, many national security experts have suggested that there is a need for a more directly applicable, comprehensive domestic terrorism statute.

\section{Recommendation 2: Consider a Rights-Protecting Domestic Terrorism Statute}

- Current statutes outline terrorist acts, as well as a comprehensive approach to countering support for a foreign terrorist organization. ${ }^{124}$ Some argue that a new statute could fill gaps within what is considered a terrorist act to fit the modern threat and/or more broadly address the threat of domestic terrorism, providing more tools for the investigation and prosecution of groups and individuals examined in this report. Doing so could be a potent tool for law enforcement, including providing more resources, as well as appropriate charges and penalties for perpetrators.

Just as the current foreign terrorism statute is intended to criminalize acts that support terrorist organizations overseas, even where such acts take place within the United

https://extremism.gwu.edu/sites/g/files/zaxdzs2191/f/Jarrett\%20William\%20Smith\%20Detention\%20 Order.pdf

122 “U.S. Army Specialist with Links to Neo-Nazi Group Pleads Guilty," Anti-Defamation League, (February 11, 2020). https://www.adl.org/blog/us-army-specialist-with-links-to-neo-nazi-group-pleadsguilty

${ }^{123}$ However, the potential to designate, "existing groups and movements, much as we use existing authorities to designate FTO's," has been raised by numerous individuals, including Elizabeth Neumann, Assistant Secretary for Threat Prevention and Security Policy at the Department of Homeland Security in her prepared remarks at The Washington Institute for Near East Policy Counterterrorism Lecture Series on March 2, 2020. See https://www.washingtoninstitute.org/uploads/Documents/other/NeumannStatement-20200302.pdf; Jason M. Blazakis, "American Terrorists: Why Current Laws Are Inadequate for Violent Extremists at Home," Lawfare, (December 2, 2018). https://www.lawfareblog.com/americanterrorists-why-current-laws-are-inadequate-violent-extremists-home; Clint Watts, "How to Fight the New Domestic Terrorism," The Wall Street Journal, (August 9, 2019). https://www.wsj.com/articles/how-tofight-the-new-domestic-terrorism-11565363219; Clint Watts, "America Has A White Nationalist Terrorism Problem. What Should We Do?” Foreign Policy Research Institute, (May 1, 2019). https://www.fpri.org/article/2019/05/america-has-a-white-nationalist-terrorism-problem-what-shouldwe-do/;

${ }^{124}$ See 18 U.S.C. $2339 A$ and 2339B 
States or the perpetrators are Americans, a new domestic terrorism statute should encompass an array of predicate criminal acts that take place in the United States and are not in support of an FTO. Such a statute could sweep into its purview not only the currently existing predicate acts, which number over 5o, but would also be expanded to include others that have been omitted, such as stockpiling weapons to further a domestic terrorist plot. ${ }^{125}$

The current FTO statute, 18 U.S.C. $§ 2339$ B prohibits the provision of material support or resources to designated foreign terrorist organizations. On the other hand, 18 U.S.C. $\S 2339$ A can be used to prosecute, "whoever provides material support or resources or conceals or disguises the nature, location, source, or ownership of material support or resources, knowing or intending that they are to be used in preparation for, or in carrying out," one of the numerous terrorism offenses.

There are currently a range of laws, including the 51 predicate offenses defined under 18 U.S.C $\S 2332 \mathrm{~A},{ }^{126}$ that could be applied in cases of domestic terrorism. However, many of these offenses-from the participation in nuclear and weapons of mass destruction threats to genocide-do not reflect the tactics, techniques, or procedures of this new wave of domestic terrorists, such as members of The Base or Atomwaffen Division. ${ }^{127}$

The national security community is exploring ways to fill gaps in our legal statutes without violating constitutionally-protected rights, to the extent possible to adequately counter this wave. One option is to add other predicate acts to the current list. Another option is a comprehensive new statute that would expand the list of predicate 18 U.S.C $\S$ 2339A offenses through the creation of an offense that is expressly designated as "domestic terrorism."

${ }^{125}$ For more, see: Mary McCord, "Filling the Gap in Our Terrorism Statutes," The Program on Extremism at The George Washington University, (August 2019).

https://extremism.gwu.edu/sites/g/files/zaxdzs2191/f/Filling\%20The\%20Gap\%20in\%20Our\%20Terrori sm\%20Statutes.pdf; Neil MacFarquhar, “As Domestic Terrorists Outpace Jihadists, New U.S. Law Is Debated," The New York Times, (February 25, 2020).

https://www.nytimes.com/2020/02/25/us/domestic-terrorism-laws.html; Mary B. McCord, "It's Time for Congress to Make Domestic Terrorism a Federal Crime," Lawfare, (December 5, 2018).

https://www.lawfareblog.com/its-time-congress-make-domestic-terrorism-federal-crime; Mary B. McCord, "White nationalist killers are terrorists. We should fight them like terrorists," The Washington Post, (August 8, 2019). https://www.washingtonpost.com/outlook/white-nationalist-killers-areterrorists-we-should-fight-them-like-terrorists/2019/08/08/3f8b761a-bg64-11eg-bad6-

609f75bfd97f story.html; Mary B. McCord, "Criminal Law Should Treat Domestic Terrorism as the Moral Equivalent of International Terrorism,” Lawfare, (August 21, 2017).

https://www.lawfareblog.com/criminal-law-should-treat-domestic-terrorism-moral-equivalentinternational-terrorism; Byron Tau and Sadie Gurman, "Legal Constraints Hobble FBI's Fight Against Domestic Terror," The Wall Street Journal, (August 22, 2019). https://www.wsj.com/articles/legalconstraints-hobble-fbis-fight-against-domestic-terror-11566478801

${ }^{126}$ As Michael German notes, Statute 18 U.S.C $§ 2332 \mathrm{~b}(\mathrm{~g})(2)$ defines these 57 predicate offenses as federal crime(s) of terrorism. 51 of them can be "independently used to prosecute cases of domestic terrorism."

Michael German, Sara Robinson, Wrong Priorities on Fighting Terrorism, Brennan Center for Justice, October 31, 2018. https://www.brennancenter.org/sites/default/files/2019-

08/Report Wrong Priorities Terrorism.pdf

127 "U.S. Code § 2339A. Providing material support to terrorists," Legal Information Institute, Cornell Law School. https://www.law.cornell.edu/uscode/text/18/2339A 
Such a comprehensive new statute could be based on 18 U.S.C $\S 2332 \mathrm{~B}-$ Acts of terrorism transcending national boundaries-and, once added to the list of predicate 18 U.S.C § 2339A offenses (amended to fill the aforementioned gaps). This, proponents argue, would provide an additional tool to the government, allowing the investigation and prosecution of individuals who commit specific, narrowly-defined acts with the intent to engage in domestic terrorism as currently defined under U.S. law - that is, "to intimidate or coerce a civilian population," "to influence the policy of a government by intimidation of coercion," or, "to affect the conduct of a government by mass destruction, assassination, or kidnapping," within the United States. ${ }^{128}$

Had it been in place, such a comprehensive domestic terrorism statute may have allowed for criminal charges that more accurately fit the actual actions and intentions of The Base and Atomwaffen defendants. Some, particularly in law enforcement, believe that this could have resulted in earlier interdiction of these extremists' activities and longer sentences. Moreover, many argue that there is an inherent value in terms of having federal criminal law clearly signal the seriousness of the fight against domestic extremists by making it possible for members of The Base, such as Patrick Mathews, and well as members of Atomwaffen like Kaleb Cole, to face charges of providing material support for domestic terrorism.

Expanding federal criminal law in this way, rather than depending only upon the creative use of existing federal and state criminal charges, could also prove an effective tool for prosecuting lone actors, or individuals who are not members of a designated foreign terrorist organization. An illustrative example of this type of lone actor is Christopher Hasson, a Lieutenant in the United States Coast Guard, who was not affiliated with an organization like The Base or Atomwaffen, but whose activities posed a very significant threat. Hasson, like the members of organized extremist groups discussed in this paper, was stopped by prosecutors who were forced to rely on a patchwork of laws. ${ }^{129}$

Christopher Hasson was arrested on February 15, 2019, and charged in federal court with unlawful possession of silencers, possession of firearms by a drug addict and unlawful user of a controlled substance, and possession of a controlled substance. ${ }^{130}$ Hasson had stockpiled firearms, "with the intent to commit mass shootings to establish a white homeland," but did not face charges of providing material support to terrorists,

\footnotetext{
${ }^{128}$ Crucially, such a statute would apply to all forms of terrorism within the United States, regardless of ideology. As scholars have argued, there is inherent value in the government penalizing all acts that fit the definition of terrorism as such, regardless of international links or whether the act transcends national boundaries. See Mary B. McCord, "It's Time for Congress to Make Domestic Terrorism a Federal Crime."

${ }^{129}$ Jon Lewis and Seamus Hughes, "Our laws have a problem calling domestic terrorism what it is," The Hill, (February 6, 2020). https://thehill.com/opinion/national-security/481166-our-laws-have-aproblem-calling-domestic-terrorism-what-it-is

130 "Christopher Hasson Facing Federal Indictment for Illegal Possession of Silencers, Possession of Firearms by a Drug Addict and Unlawful User, and Possession of a Controlled Substance," Office of Public Affairs, U.S. Department of Justice, (February 27, 2019). https://www.justice.gov/usao$\mathrm{md} / \mathrm{pr} /$ christopher-hasson-facing-federal-indictment-illegal-possession-silencers-possession
} 
or any terrorism charges stemming from his plans to commit an act of targeted violence in the United States.

Rather, he faced charges of unlawful possession of a silencer, possession of firearms by a user or addict of a controlled substance, and possession of controlled substances. ${ }^{131}$ After pleading guilty, Hasson was sentenced on January 31, 2020, to 160 months (over 13 years) in prison. ${ }^{132}$

Ultimately Hasson did receive a substantial sentence for these offenses, including a sentencing enhancement based on guidelines for offenses "that involved, or [were] intended to promote, a federal crime of terrorism." 133 Opponents of a new comprehensive federal domestic terrorism law point to this fact as reason why a new statute is unnecessary. They also point to the lack of similar cases as evidence that a comprehensive new statute, with its attendant risk of misuse or abuse, is unnecessary. However, the sentence lengths sought by the government in the cases discussed in this paper are generally lower than those sought in cases of Islamic State-related terrorism cases, which could be indicative of the insufficiencies of the current approach to counter the rising threat of domestic terrorism. ${ }^{134}$ More research is needed to compare the sentences imposed on Islamist-inspired extremists and white supremacist terrorism and the reasons for any such discrepancies, should they exist. Regardless, Hasson's case shows that there is both a need, and at least in some cases, availability for these types of enhancements, which could close the gap between sentences for terrorist crimes committed by foreign terrorists, and the (predominantly white supremacist-inspired) domestic ones on the other.

The enactment of a domestic terrorism statute could also help ensure that arrested domestic terrorists are not released into the community, but held in pretrial detention. In the absence of such a statute, prosecutors faced with suspects who are planning acts of domestic terror, but have not yet actually engaged in attacks, may be forced to rely on more minor charges that may not accurately represent the real risks at stake or what we

\footnotetext{
${ }^{131}$ Mary McCord, "Filling the Gap in Our Terrorism Statutes.”; Jon Lewis and Seamus Hughes, "Our laws have a problem calling domestic terrorism what it is," The Hill, (February 6, 2020).

https://thehill.com/opinion/national-security/481166-our-laws-have-a-problem-calling-domesticterrorism-what-it-is

132 "Christopher Hasson Pleads Guilty to Federal Charges of Illegal Possession Of Silencers, Possession Of Firearms By An Addict To And Unlawful User Of A Controlled Substance, And Possession Of A Controlled Substance," Office of Public Affairs, U.S. Department of Justice, (October 3, 2019).

https://www.justice.gov/usao-md/pr/christopher-hasson-pleads-guilty-federal-charges-illegalpossession-silencers-possession; "Christopher Hasson Sentenced to More Than 13 Years in Federal Prison on Federal Charges of Illegal Possession of Silencers, Possession of Firearms by an Addict to and Unlawful User of a Controlled Substance, and Possession of a Controlled Substance," Office of Public Affairs, U.S. Department of Justice, (January 31, 2020). https://www.justice.gov/usao-md/pr/christopher-hassonsentenced-more-13-years-federal-prison-federal-charges-illegal

${ }^{133}$ United States Sentencing Commission, “Guidelines Manual,” §3A1.4 - TERRORISM, (2018). https://guidelines.ussc.gov/gl/\%C2\%A73A1.4

${ }^{134}$ Data collected by the Program on Extremism on Islamic State-related prosecutions in the United States shows the average sentence length for the 204 known individuals to be 13.6 years. See:

"ISIS in America," The Program on Extremism at The George Washington University.

https://extremism.gwu.edu/isis-america
} 
now know to be the modus operandi of so many violent white supremacist extremists. In some circumstances, a clearly dangerous individual who can only be charged with nonviolent offences could be set free before trial, potentially putting the public in danger. This was the case in April of 2020, when federal judges ordered the release of two recently arrested members of Atomwaffen Division.

As detailed earlier, both Taylor Ashley Parker-Dipeppe and Johnny Roman Garza received federal charges for conspiring to mail threatening communications and to commit cyberstalking, and judges ruled in each of their initial hearings that no combination of conditions imposed alongside their release could ensure the safety of others and the community if they were to be released. However, in the midst of the COVID-19 pandemic, both were released. While the exact reasoning for the release of Parker-Dipeppe and Garza has not yet been made public, the absence of terrorism charges and non-violent charges against the pair may have had an impact. ${ }^{135}$

It is crucial that legal and prosecutorial responses are proportional, rule-of-law-based, and flexible to adapt to this fluid and adaptive threat. The current system may fuel the misconceptions that the government cares more about prosecuting Muslims as terrorists; not only is it important to treat these similar threats proportionally, but to call terrorism terrorism. Race or religion should not determine whether an attempt to violently coerce a civilian population confers the label of 'terrorist.'

In cases like those described, individuals have been found planning acts of targeted violence in the United States, but the charges brought against them do not always clearly reflect that. Appropriately, the FBI and DOJ, in public statements, label these individuals neo-Nazis and domestic terrorists in press releases and court filings. However, prosecutors lack explicit charges of "domestic terrorism" to levy against them, which can have an impact on pretrial detention, post-sentence or post-release measures.

After an act of targeted violence takes place, state and federal governments can avail themselves of criminal statutes, such as state capital murder and federal hate crimes, to prosecute lone actors who commit acts of violence-such as the perpetrators of the Pittsburgh and Charlottesville white supremacist attacks-and they typically ensure lengthy prison sentences. While it is reassuring that there are such tools available to prosecute the perpetrators, the tragedies in those cases have already accomplished many of their intended purposes and torn apart the victim communities. Where there are arguably gaps is in interdicting and disrupting these plots before they take place, whenever possible. To that end, many observers, including those in law enforcement, feel strongly that sufficiently powerful legal tools are not available or not easily available to address individuals who are plotting, including engagement of overt acts to prepare for violence. To many, what is seen as a hodgepodge of charges brought against the individuals profiled in this paper, all of whom are seemingly poised to commit domestic

\footnotetext{
135 The details of the detention hearings of both Dipeppe and Garza have not yet been made public, so it cannot be said with certainty that the absence of terrorism charges was a primary reason for release especially in the midst of a global health crisis. However, the nonviolent nature of their offenses and relatively short potential sentence length based on the charges is likely to have played a role in the decisions of both judges.
} 
acts of targeted violence-cyberstalking, illegally possessing firearms, conspiring to violate citizens' rights-shows the potential gaps in efficiency and effectiveness in the context of today's modern terrorism threat.

As options for a statute are considered, their benefits to law enforcement must be carefully weighed against the risks to civil liberties. Significant constitutional questions are raised by any statute addressing terrorism issues and must be taken into account as part of the totality of issues raised by a new law.

The difficult challenge to addressing this need is how to do so without unintended consequences, particularly for members of minorities and other groups whose politics and association around those politics, and often whose identities themselves (e.g., LGBTQ+, Muslim religion, race) have led some of these communities and organizations that represent them to feel that they, at times, have been unjustly labeled as terrorists. This is the basis for the opposition to a new criminal domestic terrorism statute from much of the organized civil rights community, as well as from many members of Congress. At least as a first step, however, there are a number of approaches advocated here on which there is broader consensus.

\section{Recommendation 3: Expand Information Sharing}

This report outlines the challenges to investigating and prosecuting racially and ethnically motivated extremism to interdict modern threats. Addressing those challenges writ large requires a whole-of-government and whole-of-society toolkit. ${ }^{136}$

The National Counterterrorism Center (NCTC) was established post-9/11 to, "produce integrated and interagency-coordinated analytic assessments on terrorism issues and publishes warnings, alerts, and advisories as appropriate." In practice, NCTC acts as an internal clearinghouse to take intelligence and information from law enforcement and the intelligence community and, in turn, provide information to law enforcement and intelligence agencies that are authorized to see it. For example, it ensures that the FBI has all of the intelligence it is authorized to see and that the CIA has all of the law enforcement information that it is authorized to see. Similarly, border officials and state and local law enforcement are authorized to see intelligence or federal law enforcement information only in narrow parameters and in narrow circumstances; NCTC ensures they have that information without exceeding their authorities, which is critical to interdicting known and suspected terrorists because border and local law enforcement officials are typically the front line in interdiction.

\footnotetext{
${ }^{136}$ Jonathan Greenblatt and George Selim, "Addressing the National Security Threat of White Supremacist Terrorism," Lawfare, (October 18, 2019) https://www.lawfareblog.com/addressingnational-security-threat-white-supremacist-terrorism
} 
NCTC is not legally authorized to examine domestic terrorism information because it was authorized by the Intelligence Reform and Terrorism Prevention Act, which is specific to international terrorism issues. NCTC may develop expertise on domestic terrorism only as a comparison to international terrorism, which severely limits its analytical abilities, and it lacks any ability to share information on domestic terror. ${ }^{137}$

Authorizing NCTC to examine domestic terrorism analytically could be achieved through administrative action, given the applicability of broad terrorism-related analysis to include domestic terrorism to the international counterterrorism mission. But, in order to share information between the intelligence and law enforcement communities, Congress would have to pass legislation to alter its mandate. Alternatively, a new Domestic Terrorism Prevention Center could be created to use a similar mechanism as NCTC but tailored directly to the different information collection and sharing authorities inherent in domestic terrorism, such as a greater focus on state and local law enforcement and the private sector.

Given the spread of domestic extremism online-and that law enforcement's authorities to counter domestic terrorist groups are limited-the public sector role in informationsharing is critical.

The National Center for Missing and Exploited Children (NCMEC) may serve as a public-private partnership and model for information-sharing. NCMEC was formed as a non-profit with government funding and direct partnerships with federal agencies. The NCMEC serves as a coordinating body to ensure different entities get the information that they need in a timely manner and pursuant to their mission. NCMEC provides information to social media companies, and when law enforcement authorities are more appropriate, they provide information to law enforcement; this ensures that content exploiting children is provided efficiently and effectively only to those who need-and are authorized to receive-the information. The federal government could create a similar hub for information sharing to empower greater flow of domestic extremism information to help ensure information is not used improperly by the government; creating it would reduce the risk that the government will be ill-informed when information can be obtained lawfully. A NCMEC-like clearinghouse for domestic terrorism information could help mitigate the civil liberties concerns of otherwise leaving the responsibility of finding concerning content to the government.

\section{Recommendation 4: Oversight, data, and resources to better understand and address this modern threat}

\footnotetext{
${ }^{137}$ Joshua Geltzer, Mary McCord, and Nicholas Rasmussen, “The Christchurch Shooting: Domestic Terrorism Goes International," Lawfare, (March 19, 2019). https://www.lawfareblog.com/christchurchshooting-domestic-terrorism-goes-international
} 
In the past year, Congress has begun to address white supremacist violence, notably through hearings and oversight. Moreover, Congress included in the National Defense Authorization Act for Fiscal Year 2020 a requirement for increased coordination between the FBI, Department of Homeland Security, and intelligence community and an annual report on domestic terrorism. To date, the FBI and other agencies have not provided sufficiently clear data about efforts to understand the threat and how the government is responding. The data reporting requirement will require these agencies to clearly identify the threat.

\section{Recommendation 5: Pass Legislation to Properly Resource to the Threat}

Congressional action is needed to properly counter the rising threat of domestic terrorism. Bipartisan legislation is needed to enhance the federal government's efforts to prevent domestic terrorism by authorizing law offices that are focused specifically on this threat, and requiring federal law enforcement agencies to regularly assess the threat of white supremacy and apportion resources based on that analysis. Such legislation should also provide training and resources to assist non-federal law enforcement in addressing these threats, requiring DOJ, DHS, and the FBI to provide training and resources to assist state, local, and tribal law enforcement in understanding, detecting, deterring, and investigating acts of domestic terrorism. Swift passage of legislation of this kind by the House and Senate would increase the focus of the federal government on domestic terrorism and allow Congress to do better oversight of these efforts.

\section{Recommendation 6: Prevent the next generation of threats}

Extremist threats now move at the speed of the internet, and the social divisiveness that can exacerbate extremism must be met with community resilience to heal community divides. For those reasons and more, we must invest in preventing targeted violence and violent extremism, in our communities as well as online. To date, efforts to prevent extremism have been overwhelmingly focused on Islamist-inspired extremist threatswe need immediate and uncontroversial investments in prevention to change the trajectory of extremism in the United States as soon as possible. 138

Civil society and other actors can help create off-ramps to prevent individuals from taking up violent extremists' cause. Investments in academic institutions to research what works in prevention, training law enforcement on white supremacy and extremism, and empowering local communities through civil society are critical to preventing the next extremists. Given that these extremists frequently plot against religious institutions, those deemed high risk should have access to security measures to reduce their vulnerability to attack.

A precursor to extremism is hate; hate crimes may not be as severe as terrorism, but they are far more widespread, and their permissiveness breeds greater likelihood for

\footnotetext{
${ }^{138}$ Ryan B. Greer and George Selim, "Reframing Prevention: If Government Won't Lead, Civil Society Must Step Up to Curb Extremism," Just Security, (December 10, 2018).

https://www.justsecurity.org/61755/reframing-prevention-government-lead-civil-society-step-curbextremism/
} 
extremism and have impacts far beyond those targeted. More attention must be given to investigating and prosecuting hate crimes, as well as to collect information on them to improve transparency and reporting. Grants and other support could improve local and state hate crime training, prevention, best practices, and data collection initiatives-such as hate crime reporting hotlines to direct individuals to local law enforcement and support services.

In our modern era, online communities must be given careful attention, and that must start with the private sector. Technology companies must recognize their role in being part of the solution, including having clear terms of service regarding hateful and extremist content, as well as consequences for violating them.

\section{Recommendation 7: Speak out and educate the public}

Domestic extremist groups seek to mainstream their message, even sometimes purposefully sounding less extreme in order to garner support without raising alarm. ${ }^{139}$ Speaking out can not only prevent this mainstreaming, but also make it less socially acceptable to espouse these views. All community members-whether in the White House or a city council-should always speak out against hatred and bigotry, including our nation's top leaders.

139 “Tree of Life Shooting Revives ‘Optics’ Debate Among White Supremacists,” Anti-Defamation League, (November 6, 2018). https://www.adl.org/blog/tree-of-life-shooting-revives-optics-debate-among-whitesupremacists 